I NTERNATIONALMONETARY F U N D African Department

\title{
Public Investment Efficiency in Sub-Saharan African Countries
} What Lies Ahead?

Karim Barhoumi, Ha Vu, Shirin Nikaein Towfighian, and Rodolfo Maino

No. $18 / 09$ 


\section{Public Investment Efficiency in Sub-Saharan African Countries What Lies Ahead?}

Karim Barhoumi, Ha Vu, Shirin Nikaein Towfighian, and Rodolfo Maino 
Copyright @2018 International Monetary Fund

\title{
Cataloging-in-Publication Data
}

\author{
Joint Bank-Fund Library
}

Names: Barhoumi, Karim. | Vu, Ha. | Towfighian, Shirin Nikaein. | Maino, Rodolfo, 1961- | International Monetary Fund. | International Monetary Fund. African Department.

Title: Public investment efficiency in Sub-Saharan African countries : what lies ahead? / Karim Barhoumi, Ha Vu, Shirin Nikaein Towfighian, and Rodolfo Maino.

Other titles: International Monetary Fund. African Department (Series)

Description: Washington, DC : International Monetary Fund, 2018. | Departmental paper series | At head of title: The African Department. | Includes bibliographical references.

Identifiers: ISBN 9781484360019 (paper)

Subjects: LCSH: Public investments—Sub-Saharan Africa. | Bank loans—Sub-Saharan Africa. | Economic development-Sub-Saharan Africa.

Classification: LCC HC800.Z9 P832 2018

The Departmental Paper Series presents research by IMF staff on issues of broad regional or cross-country interest. The views expressed in this paper are those of the author(s) and do not necessarily represent the views of the IMF, its Executive Board, or IMF management.

Publication orders may be placed online, by fax, or through the mail: International Monetary Fund, Publication Services P.O. Box 92780, Washington, DC 20090, U.S.A.

Tel. (202) 623-7430 Fax: (202) 623-7201

E-mail: publications@imf.org www.imfbookstore.org www.elibrary.imf.org 


\section{Contents}

Acknowledgments.....................................................................................................v

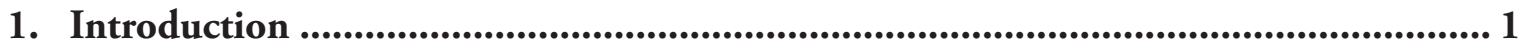

2. Investment in Sub-Saharan African Countries: Where Do We Stand? ....................... 5

3. Assessing Public Investment Efficiency in Sub-Saharan African Countries.............. 11

4. Explaining Public Investment Efficiency in Sub-Saharan African Countries ........... 15

5. Reducing the Efficiency Gap in Sub-Saharan Africa .......................................... 19

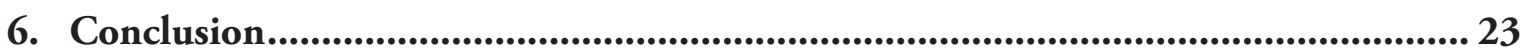

Annex 1. Public Investment Management Assessment................................................ 25

Annex 2. Data Envelopment Analysis Methodology................................................... 29

Annex 3. Alternative Methodology ...................................................................................... 33

Figures

1. Trends in Investment and Capital Stock, 2000-15 .............................................6

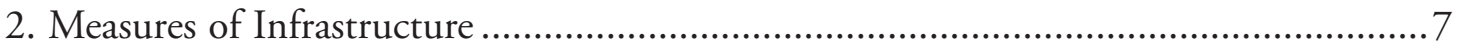

3. Selected Quantitative Indicators of Infrastructure, 2015 ...................................... 7

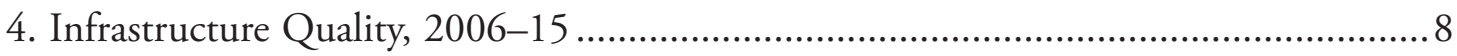

5. Real Public Investment and Quality of Overall Infrastructure, 2015 .........................

6. GDP per Capita versus Gross Fixed Capital Formation, 2015 ................................. 10

7. Efficiency Gap in Sub-Saharan African Countries .................................................. 13

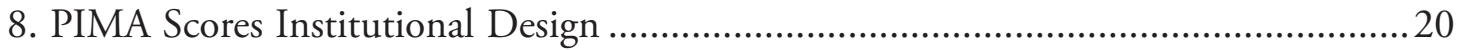

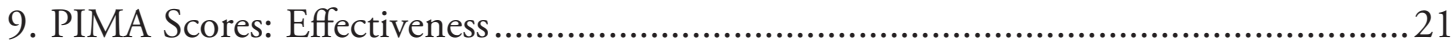

10. PIMA Scores Institutional Design and Effectiveness..........................................22

Annex Figure 1.1 Public Investment Management Assessment Framework ..................27

Annex Figure 2.1 Efficiency Frontier ..................................................................... 30

Annex Figure 2.2 Technical and Allocative Efficiency Measures.................................. 31

Tables

1. Average Public Investment Efficiency Index by Regional Group.............................. 13

2. Average Public Investment Efficiency Index........................................................ 14

3. Determinants of Public Investment Efficiency...................................................... 17

4. Determinants of Public Investment Efficiency, Alternative Methodology .................. 18 
Annex Table 3.1 Hybrid Efficiency Score-Ordinary Least Squares ............................. 34

Annex Table 3.2 Survey-Based Efficiency Score-Ordinary Least Squares ......................35

Annex Table 3.3 Physical Efficiency Score_Ordinary Least Squares.............................36

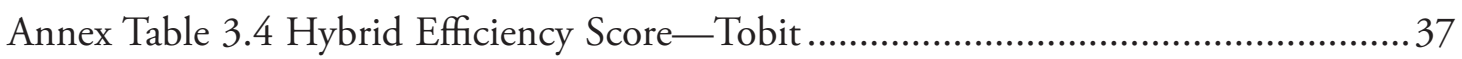

Annex Table 3.5 Survey-Based Efficiency Score-Tobit............................................... 38

Annex Table 3.6 Physical Efficiency Score-Tobit.........................................................39

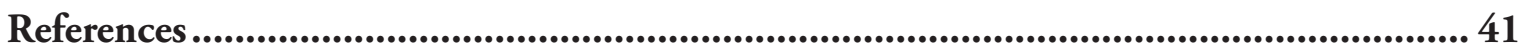




\section{Acknowledgments}

The authors thank Anne-Marie Gulde-Wolf, Dominique Desruelle, Annalisa Fedelino, Norbert Toé, Axel Schimmelpfennig, Benedict Clements, and the members of the Research Advisory Group in the African Department for comments and suggestions, and assume responsibility for any remaining errors. Christelle Ndome-Yandun provided excellent editorial assistance. 



\section{ChAPTER}

\section{1 intoduction}

Investment-by both private and public entities — is a key driver of growth and job creation. ${ }^{1}$ In the short term, both public and private investment can affect output and employment by increasing aggregate demand. Over time, private investment contributes to potential output and job creation by directly expanding the economy's productive capacity. It can also boost productivity through the introduction of new production techniques and processes - particularly in the case of foreign direct investment (FDI). Public investment also induces supply-side effects through several channels. Given its highly complementary nature, it is a catalyst for private sector development and productivity growth. Reliable transportation, energy, and communication infrastructures are paramount to unlocking private sector investment. Good education and health systems are also key to building human capital and enhancing competitiveness and productivity.

Less attention has been paid to the efficiency of public investment and the factors that govern its economic and social impact. Despite widespread anecdotal evidence of projects plagued by cost overruns, time delays, and inadequate maintenance, robust empirical analyses of the determinants of public investment efficiency are relatively scarce. Warner (2014) examined five episodes of public investment "surges" and found limited impact on long-term growth, owing in part to weak or circumvented project appraisal, selection, and management procedures. In a comprehensive study of 52 developing countries, Gupta and others (2014) found the strength of public investment management (PIM) to be a significant determinant in the relationship between public investment and growth. Using a survey of its own experts, McKinsey Global Institute (2013) identified \$1 trillion in potential efficiency gains from improvements in PIM around the globe. However, Berg

\footnotetext{
${ }^{1}$ For analyses of the positive impact of total investment on growth, see Barro and Lee (1993), Aghion and Howitt (2009), and Bornhorst and others (2010).
} 
and others (2015) have noted that the net impact on growth of a marginal increase in public investment also depends on the initial capital stock. The intuition for this result arises from the fact that the marginal contribution of an additional dollar of investment spending to output depends on the amount of capital actually installed and the marginal productivity of that capital. A country with permanently low efficiency has been installing less capital, resulting in a lower public capital stock. On the other hand, assuming decreasing returns to factors of production implies a higher marginal productivity of public capital. Berg and others (2015) argue that these two effects go in opposite directions in terms of the effect of additional investment spending on output.

In sub-Saharan African countries, promoting high-quality investment has long been a central policy challenge. Numerous studies over the past two decades have stressed the insufficient level of private (both domestic and foreign) investment and the lack of public investment (see, for example, OECD 2014; World Bank 2011; IMF 2014, 2015b) as key constraints on growth and job creation. Significant emphasis has also been placed on the quality of investment. For public investment, the focus has been on institutions and processes aimed at promoting government capital outlays with high growth and employment impact (IMF 2014). Regarding private investment, studies have highlighted the need to promote effective allocation of capital, away from the hydrocarbon sector and energy-intensive industries (particularly for oil exporters) and toward sectors that promote sustainable growth and job creation.

Over the past 15 years, privately funded infrastructure investment in sub-Saharan Africa has been on the rise. With a variety of modalities ranging from concessions and public-private partnerships (PPPs) to equity investment, syndicated loans, and infrastructure bonds, bank lending has been the major source of private financing for sub-Saharan African infrastructure projects. This situation reflects the limited development of other sources of private funding as well as a number of factors that make bank lending particularly suitable for project finance. Bank lending ensures a more direct relationship between borrower and lender than other debt funding sources, such as the bond market, do. This direct relationship can minimize negotiation time and avoid the costs involved in securing a formal credit rating. The following are additional factors in favor of bank lending:

- Banks may be more willing to finance greenfield infrastructure projects because they have a more direct overview of the project and greater ability to manage construction risk. However, unlike nonprivate sources of financing, bank credit is sensitive to changes in funding conditions, global risk aversion, and prudential regulation. As illustrated in Section III, these 
"push" factors are critical in explaining the decline in cross-border bank credit in the aftermath of the 2008-09 crisis. They also account for the changing structure of bank flows from traditional to new bank lenders.

- The impact of global factors on bank financing of sub-Saharan African infrastructure has been substantial. In the past, traditional European bank lenders (from France, Germany, and the United Kingdom) were the major contributors to sub-Saharan African infrastructure financing; in the aftermath of the 2008-09 crisis these lenders have scaled back their participation in new syndicates and large bilateral loans. Their contribution reached a historical low in 2014. The gap in development financing left by the retrenchment of traditional European banks has not been filled by the new foreign bank lenders that have entered the market (Section III); in fact, the contribution of these new lenders to sub-Saharan African infrastructure financing has remained very limited. Nonetheless, alternative forms of financing, such as FDI flows, tend to be concentrated in some countries in sub-Saharan Africa, even in some that are not resource-intensive-for example, Mauritius, Mozambique, Seychelles, São Tomé and Príncipe, The Gambia, and Cabo Verde. Some countries have other important sources of financial flows (portfolio and loans) - for example, Kenya, Senegal, and South Africa. In recent years, PPPs and the growth of crowdfunding have provided funding for development initiatives, families, and infrastructure projects.

- Local pan-African banks have stepped in to fill the funding gap and have become the largest participants in new syndicates and large bilateral loans to finance infrastructure. The increased role of African financial institutions in sub-Saharan African infrastructure financing is reflected in the growing number and volume of syndicated deals without foreign participation or where African banks are the lead arrangers of the syndicate.

Improving the efficiency of public investment could help sub-Saharan African countries improve infrastructure quality without a deterioration in their fiscal position. In some countries, capital spending has remained high, contributing to weaker fiscal positions and exacerbating fiscal vulnerability to the volatility of commodity prices. Countries in sub-Saharan Africa need to ensure that the scaling up of public investment, which is leading to rapidly rising debt, is steadily trimmed to normal levels consistent with continued fiscal and external sustainability. In particular, rebalancing from regressive to more progressive expenditures, revenue mobilization, and enhanced public investment efficiency can provide the resources to expand social safety nets.

This paper uses three infrastructure indicators to gauge public investment efficiency in 45 sub-Saharan African countries; the result is that sub-Saharan Africa's efficiency compares unfavorably among regional comparators. Using the data envelopment analysis (DEA), efficiency scores were estimated for 
each infrastructure indicator. Overall, sub-Saharan Africa scores are below those of comparator groups. The magnitude of the inefficiency depends on the specific efficiency score index. The results suggest that sub-Saharan African countries could increase their investment efficiency by 35 percent.

In addition, cross-country regressions suggest that the quality of institutions is the main determinant of public investment efficiency in sub-Saharan African countries. These regressions cover the period 2000-15, and the efficiency scores are a function of a set of explanatory variables such as the following: (1) the quality of institutions, measured by two World Economic Forum (WEF) indicators (control of corruption and regulatory quality); (2) official development assistance; (3) percentage of urban population; and (4) dependency on natural resources, represented by a dummy variable for countries rich in nonrenewable natural resources. Overall, the estimations show a positive correlation between public investment efficiency and the quality of institutions.

Finally, the new Public Investment Management Assessment (PIMA), developed by IMF staff, suggests that improvement in public investment management practices in sub-Saharan African countries could significantly reduce their efficiency gap. Notably, sub-Saharan African countries could improve public investment efficiency by strengthening the planning and selection of PPPs, the credibility of multiyear budgeting, the effectiveness of project appraisal and selection, the monitoring of projects during their implementation, and the registration of infrastructure assets. 


\section{ChAPTER}

\section{Investment in Sub-Saharan African}

Benchmarking the performance of infrastructure sectors in sub-Saharan African countries involves assessing economic infrastructure across two dimensions: quantity and quality. To place the infrastructure trends in sub-Saharan Africa in context, this paper uses a comparative perspective. First, the analysis examines infrastructure trends across different comparator regions; namely, emerging and developing Asia as well as Latin America and the Caribbean. Second, it assesses the infrastructure quantity and quality in sub-Saharan African.

\section{Overall Trends}

Reflecting an improvement in policies and in global conditions, investment rates in sub-Saharan African countries have increased over the past two decades. While progress has been made on policies and reforms aimed at fostering higher capital spending by both public and private entities, investment also benefited strongly from more favorable conditions. In this context, total investment rate, public investment, and private investment increased by 3.5 percent, 3 percent, and 2 percent of GDP, respectively, between 2000 and 2015. Nevertheless, investment rates in sub-Saharan African countries still lag those of peers such as in emerging and developing Asia and Latin America and the Caribbean (Figure 1). Although the real value of the public capital stock increased by about 60 percent on a per capita basis in sub-Saharan African countries between 2000 and 2015, it failed to keep pace with rising output throughout that period. 
Figure 1. Trends in Investment and Capital Stock, 2000-15 (Percent of GDP)
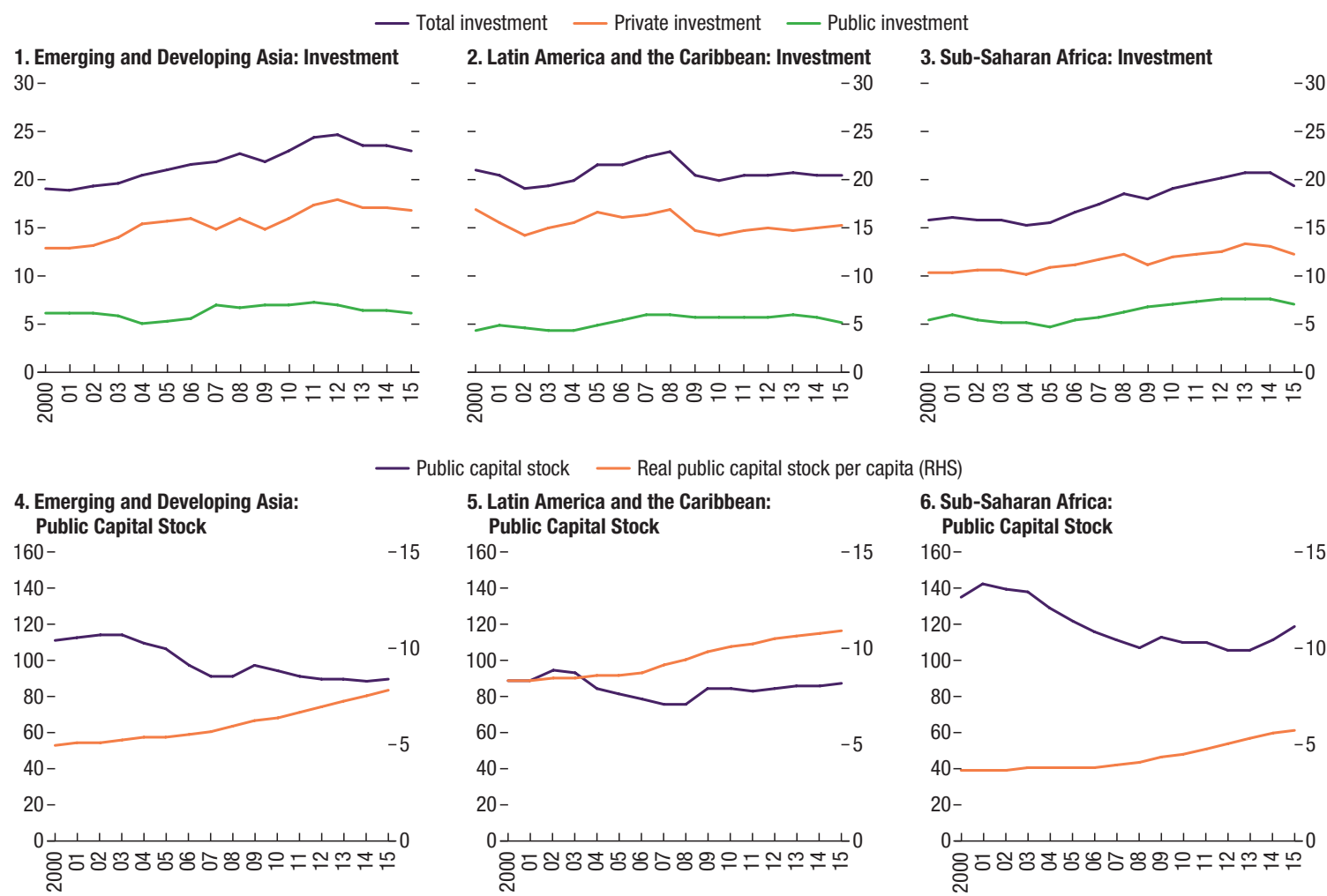

Sources: Investment and Capital Stock Dataset; and IMF staff estimates.

\section{Infrastructure Gap}

This subsection assesses the patterns of infrastructure stocks and their accumulation across countries in the region. It updates the benchmarking analysis of infrastructure in the region conducted by Calderon and Serven (2004) and confirms the continuing existence of a wide gap in infrastructure provision between sub-Saharan Africa and other regional comparators.

Despite a recent surge in investment across the region, sub-Saharan African countries have recorded an infrastructure gap compared with their peers. The infrastructure network in sub-Saharan African countries suffers from a clear deficit: sub-Saharan African countries are lagging their regional peers in electricity supply, paved road density, public education infrastructure, telecommunication infrastructure, and access to water (Figures 2 and 3). 


\section{Figure 2. Measures of Infrastructure}

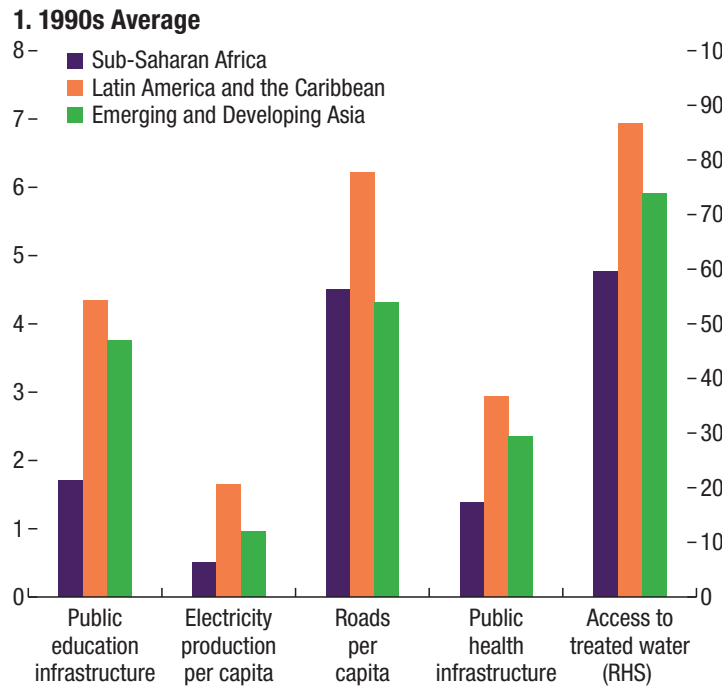

\section{Most Recent Year}

8- $\quad$ Sub-Saharan Africa -100

Latin America and the Caribbean

7- $\quad$ Emerging and

Developing Asia

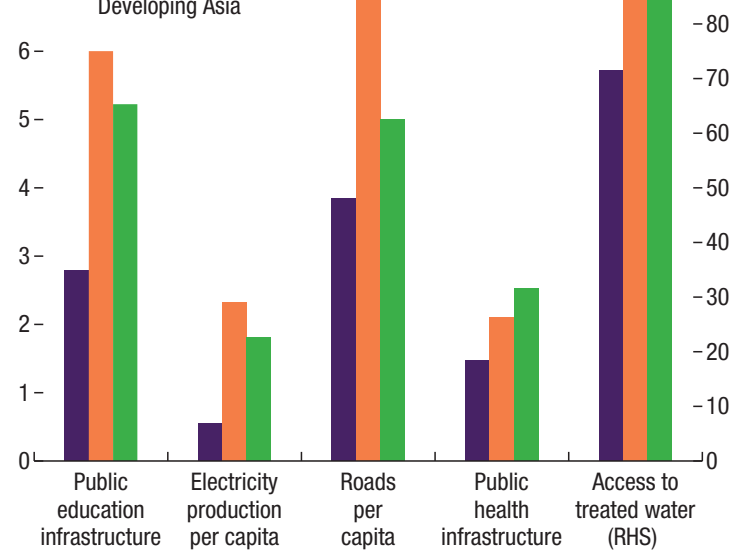

Sources: World Development Indicators; and IMF staff estimates.

Note: Units vary to fit scale. Left-hand axis: public education infrastructure is measured as secondary teachers per 1,000 persons; electricity production per capita as kWh per 1,000 persons; roads per capita as km per 1,000 persons; and public health infrastructure as hospital beds per 1,000 persons. Right-hand axis (RHS): access to treated water is measured as percent of population.

Figure 3. Selected Quantitative Indicators of Infrastructure, 2015

(Normalized indices, $L A C=1$ )

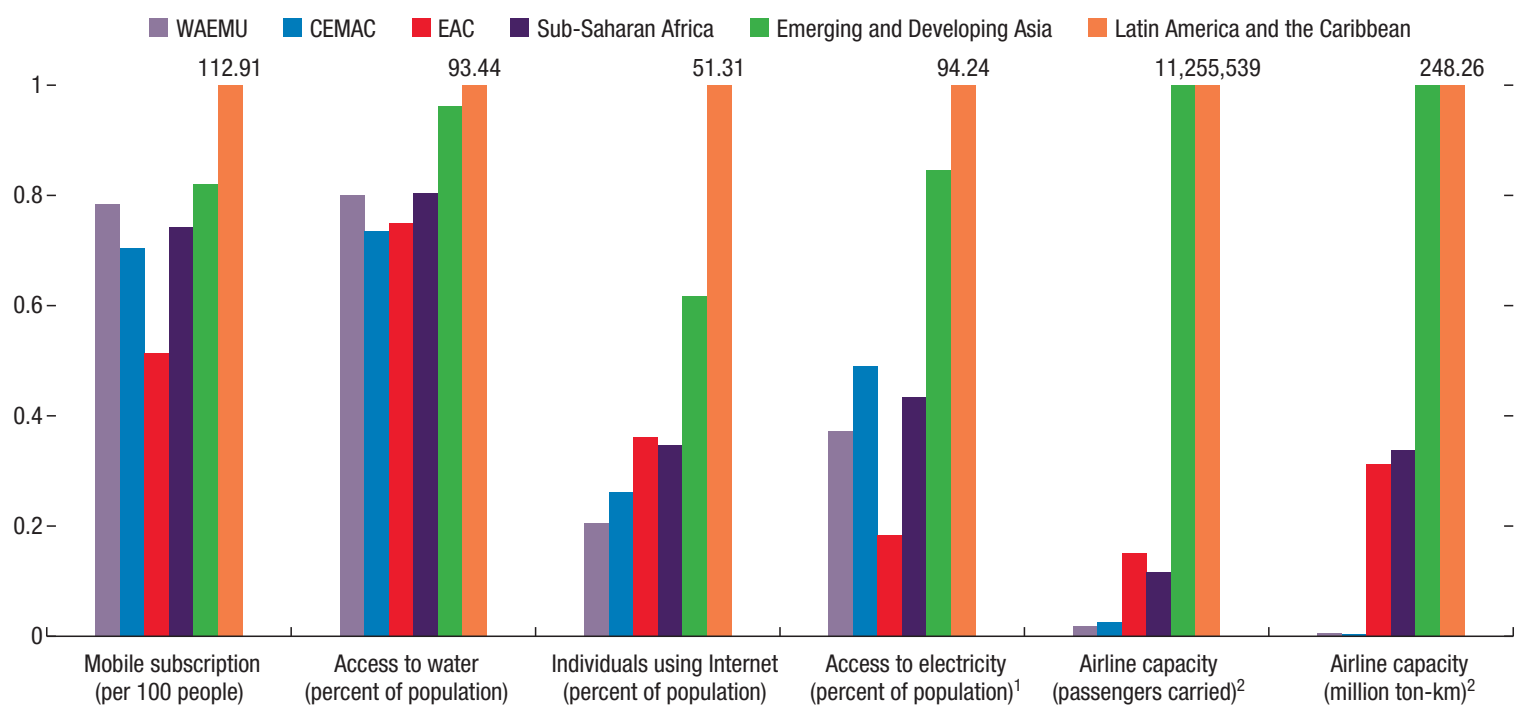

Sources: World Development Indicators; and IMF staff estimates.

Note: West African Economic and Monetary Union (WAEMU), Central African Economic and Monetary Community (CEMAC), East African Community (EAC). ${ }^{1}$ Last available data for access to electricity are from 2014.

2Emerging and Developing Asia's value for airline capacity is values for airline capacity are $3.6(40,456,902$ passengers) and 5.7 (1,410.90 million ton-km);

they are outside the scope of this figure. 
Figure 4. Infrastructure Quality, 2006-15 (Scale: $1-7$ [best])

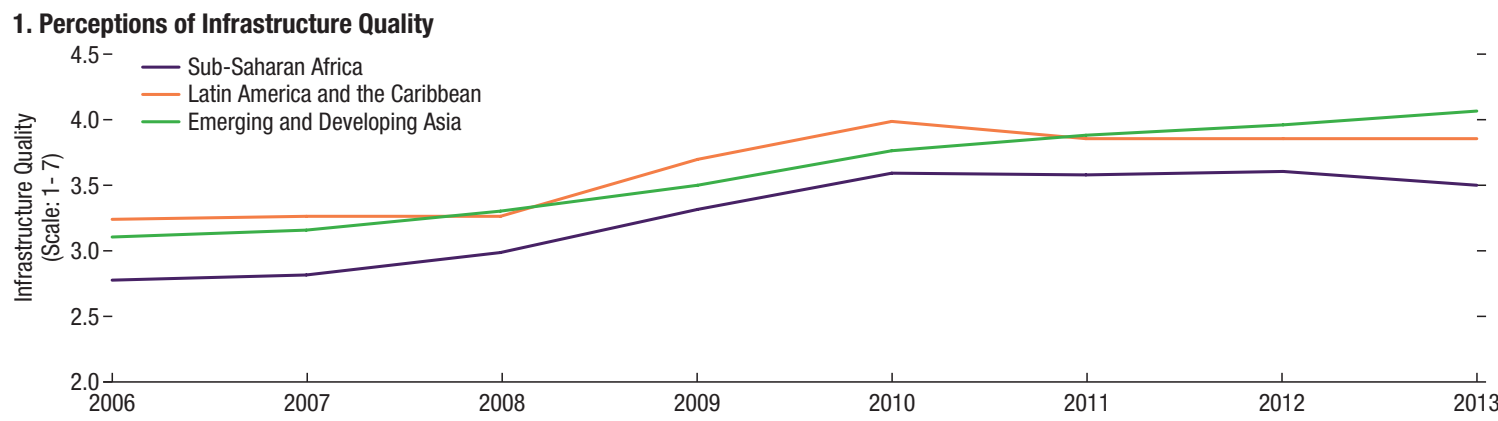

2. Selected Qualitative Indicators of Infrastructure, 2015

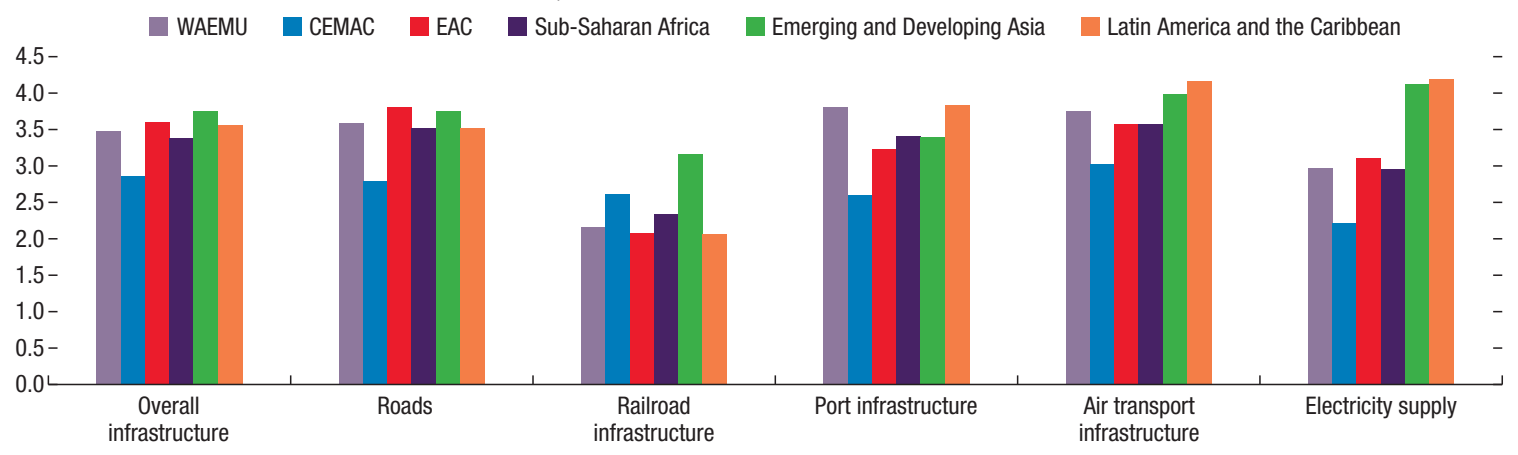

Sources: Global Competitiveness Index; and IMF staff estimates.

\section{Infrastructure Quality}

In addition to the quantity gap, the region's infrastructure is perceived as being of relatively low quality. While it is imperative for the region to reduce the gap in the quantity of infrastructure, the quality of these service-providing capital goods will be the major contributor to their optimal use. The most recent World Economic Forum Report shows that the region's overall infrastructure quality is perceived as being relatively low. The quality of electricity supply, roads, and railroads also scored below those of regional peers (Figure 4).

The low quality of infrastructure is only loosely correlated with public investment levels, pointing to significant inefficiency across sub-Saharan African countries compared with regional comparators. As shown in Figure 5, the relationship between real public capital stock per capita and perceptions of infrastructure quality is positive but relatively weak. This suggests the existence of considerable scope to enhance the efficiency and impact of public investment in most sub-Saharan African countries. 
Figure 5. Real Public Investment and Quality of Overall Infrastructure, 2015 (Scale: $1-7$ [best])

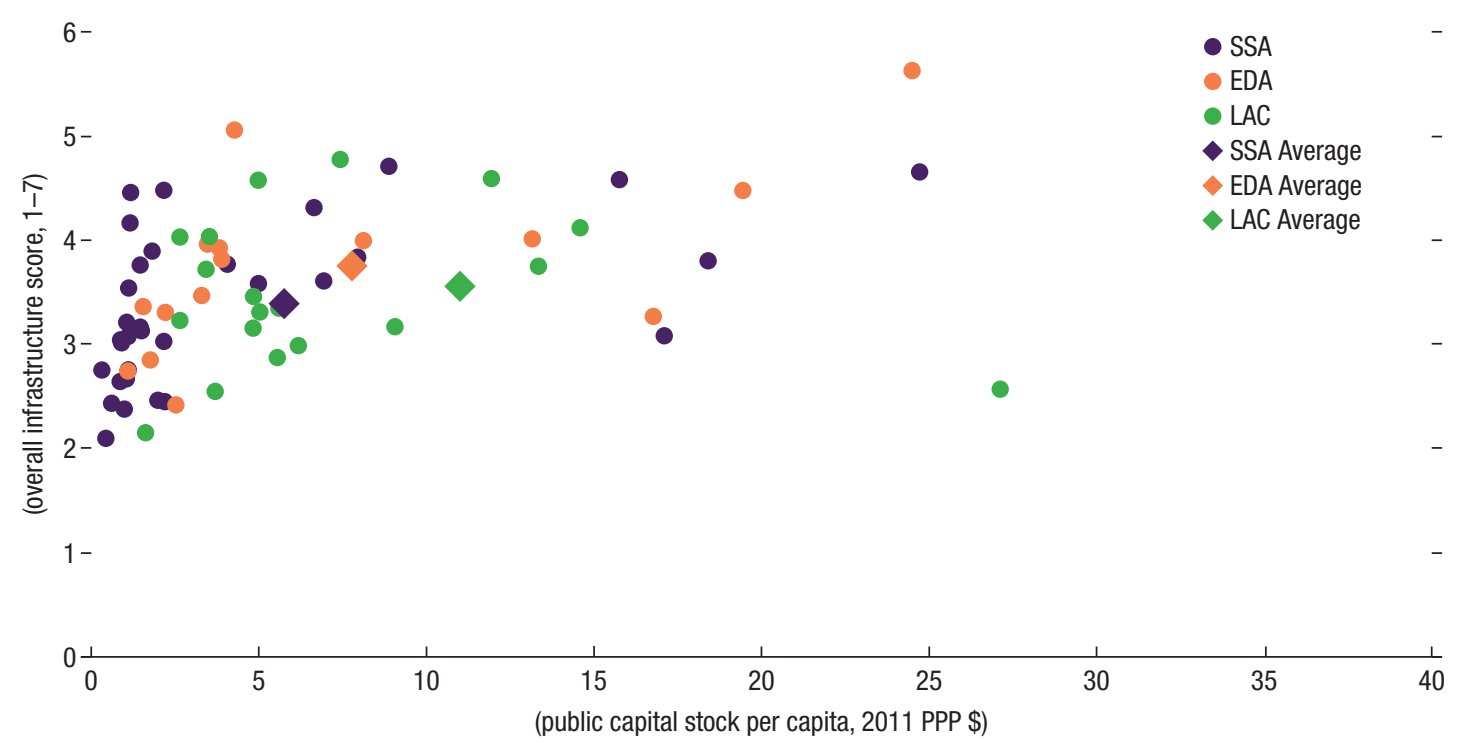

Sources: World Development Indicators, and IMF staff estimates.

Note: Sub-Saharan Africa (SSA), Emerging and Developing Asia (EDA), Latin America and the Caribbean (LAC). Equatorial Guinea and

Trinidad and Tobago are not shown in the graph as they are outliers. Public capital stock per capita is in constant 2011 international dollars.

Investment in sub-Saharan African countries appears to have been less effective in generating growth than in peer countries. The increase in investment rates over the past two decades has not been concomitant with an improvement in the growth performance throughout the region. The correlation between real GDP growth and investment during 2015 was weaker than in other parts of the world (Figure 6). 
Figure 6. GDP per Capita versus Gross Fixed Capital Formation, 2015

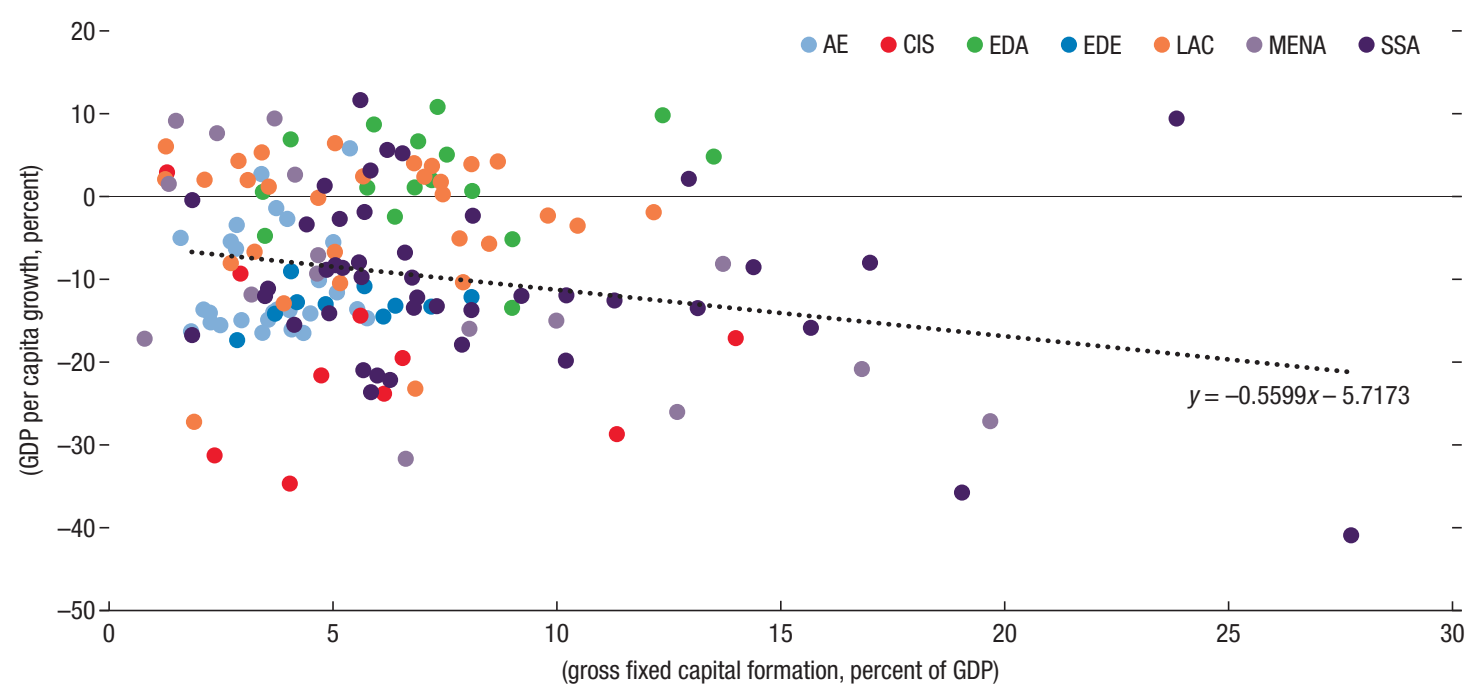

Sources: Investment and Capital Stock Database; World Economic Outlook; and IMF staff estimates.

Note: Advanced Economies (AE), Commonwealth of Independent States (CIS), Emerging and Developing Asia (EDA), Emerging and Developing Europe (EDE),

Latin America and the Caribbean (LAC), Middle East, North Africa, Afghanistan, and Pakistan (MENA), Sub-Saharan Africa (SSA). 


\section{ChAPTER}

\section{Assessing Public Investment Efficiency in Sub-Saharan African Countries}

This section uses several empirical approaches to assess the public investment efficiency for sub-Saharan African countries. Following Herrera and Pang (2005), Grigoli and Kapsoli (2013), and Albino-War and others (2014), the empirical analysis is based on the efficiency frontier analysis, which refers to the relative efficiency in translating monetary inputs into infrastructure outputs.

\section{Methodology}

The efficiency frontier analysis assesses the relative efficiency of the sub-Saharan African countries in translating public investment (inputs) into infrastructure (outputs). Following IMF (2015a), Grigoli and Kapsoli (2013), and Albino-War and others (2014), the data envelopment analysis methodology - the standard approach in the literature using nonparametric methods - is used to calculate the efficiency of public investment. The DEA is a deterministic algorithm that calculates the efficient frontier through linear approximations enveloping performance observations of all decision-making units (Annex 2). Efficiency scores are then calculated relative to a peer group consisting of linear combinations of input-output observations for efficient decision-making units. ${ }^{1}$ An output-oriented model is used to calculate efficiency scores.

The assessment of the efficiency of public investment is carried out with a two inputs-one output model over the period 1990-2015:

\footnotetext{
${ }^{1}$ The original DEA model assumes constant return to scale, which implies that all decision-making units in the sample are performing at an optimal scale. This is a strong assumption when dealing with a heterogeneous set of countries; therefore, DEA with variable return to scale is used to guarantee that each decision-making unit (country) is compared only with others that have similar characteristics.
} 
- Inputs: The first input is the real public capital stock per capita. ${ }^{2}$ The second input is per capita GDP, which is used as a proxy for the contributions of the private sector to infrastructure services.

- Outputs: To measure infrastructure output, IMF's (2015) approach was followed by using three measures of infrastructure quality and access: ${ }^{3}$

o A physical indicator, which combines data on the volume of economic infrastructure (length of road network, electricity production, and access to water) and social infrastructure (number of secondary teachers and hospital beds)

o A survey-based indicator based on the World Economic Forum's survey of business leaders' impressions of the quality of key infrastructure services

o A hybrid indicator, which combines the physical and survey-based indicators into a synthetic index of the coverage and perceived quality of infrastructure networks. It is simply the arithmetic mean of the physical and survey-based indicators and provides a measure for both coverage and perceived quality

- Efficiency Scores: Based on the three indicators of infrastructure output, there are three estimated public investment efficiency scores: (1) a physical indicator-based efficiency score, (2) a survey indicator-based efficiency score, and (3) a hybrid indicator-based efficiency score. ${ }^{4}$

\section{Empirical Results}

The overall estimation of efficiency scores shows that there is substantial scope to improve efficiency. The corresponding efficiency score for each infrastructure output index mentioned above was estimated (Table 1 and Figure 7). Under the three different estimations of efficiency scores, sub-Saharan African countries could increase their average investment efficiency between 20 percent and 54 percent with the same amount of investment.

- The average estimated efficiency score using the physical indicator for sub-Saharan Africa is 0.46 , meaning that sub-Saharan Africa has an efficiency gap of 54 percent compared with its best-performing peers. This is significantly worse than other regions. However, this estimation of efficiency does not capture the quality of infrastructure or the geographic and socioeconomic conditions and needs of individual countries.

\footnotetext{
${ }^{2}$ For details regarding the estimations of public capital stocks, see IMF (2015).

${ }^{3}$ Data are provided by the Investment and Capital Stock template prepared by the IMF Fiscal Affairs Department.

${ }^{4}$ Since efficiency score is calculated as a function of infrastructure output (that is, efficiency $=f$ [infrastructure indicator]), an efficiency score based on the hybrid indicator cannot be the average of an efficiency score based on a physical indicator and an efficiency score based on a survey indicator. In other words, $f$ (hybrid indicator) $=f[$ (physical indicator + survey indicator $) / 2] \neq[f$ (physical indicator $)+f($ survey indicator $)] / 2$.
} 
Figure 7. Efficiency Gap in Sub-Saharan African Countries
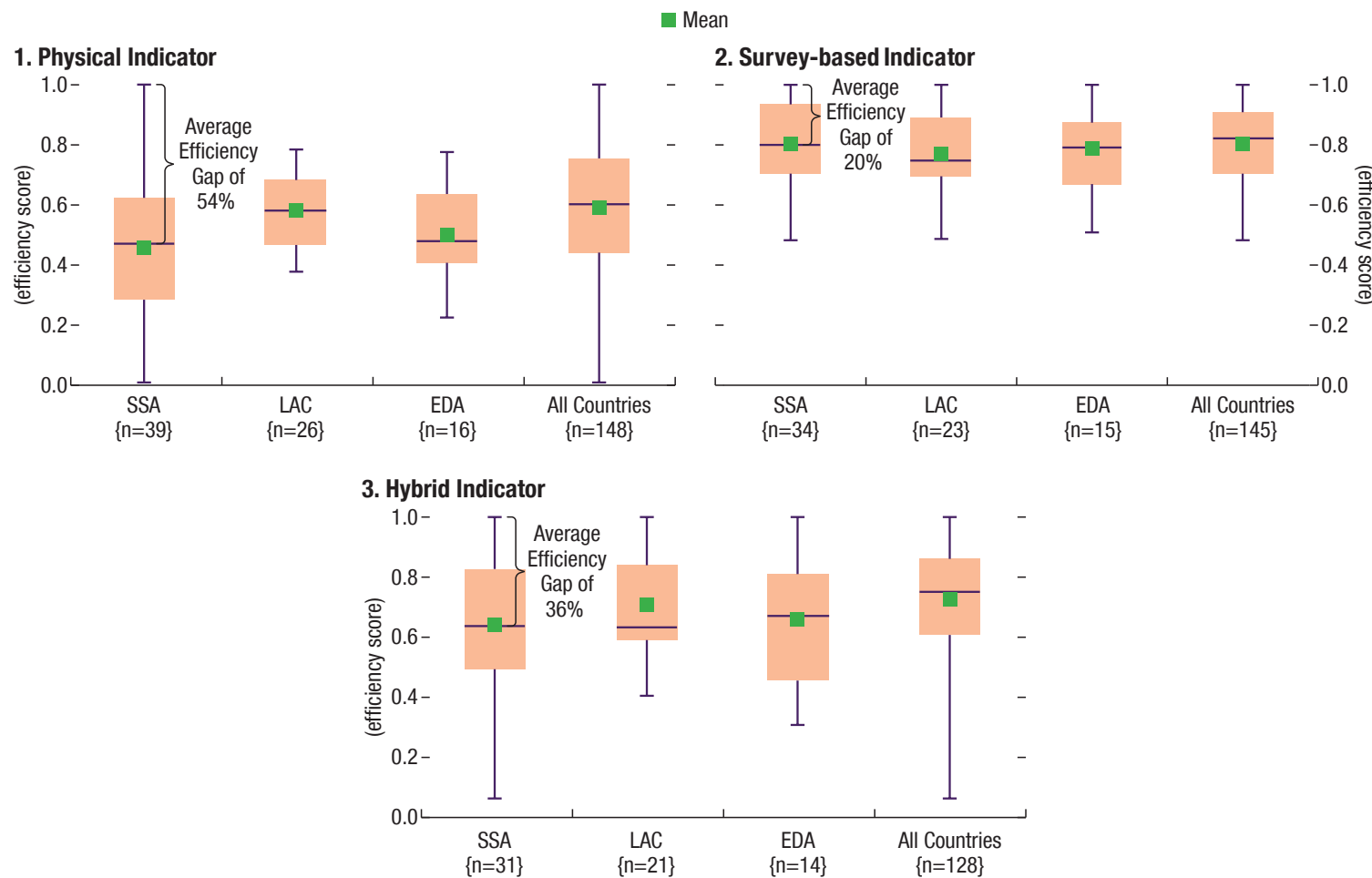

Source: IMF staff estimates

- The average estimated efficiency score using the survey-based indicator for sub-Saharan Africa is 0.80 , meaning that sub-Saharan Africa has an efficiency gap of 20 percent compared with its best-performing peers. This is comparable or slightly better than other regions. However, this estimation is based on people's perception of infrastructure, which depends on their expectations for infrastructure in each country. The expectations for infrastructure quality in sub-Saharan Africa may not be as high as those in other regions. In addition, the satisfaction of citizens might not be linearly

Table 1. Average Public Investment Efficiency Index by Regional Group

\begin{tabular}{lccc}
\hline Region & Physical indicator & Survey-based indicator & Hybrid indicator \\
\hline Commonwealth of Independent States & 0.9352 & 0.7158 & 0.7879 \\
Emerging and Developing Asia & 0.5012 & 0.7877 & 0.6591 \\
Emerging and Developing Europe & 0.7532 & 0.7078 & 0.7275 \\
Latin America and the Caribbean & 0.5803 & 0.7686 & 0.7086 \\
Middle East, North Africa, Afghanistan, and Pakistan & 0.4717 & 0.7909 & 0.6763 \\
Sub-Saharan Africa & 0.4597 & 0.8033 & 0.6417 \\
Advanced Economies & 0.7333 & 0.8883 & 0.8799 \\
\hline Source: IMF stff estimates & & &
\end{tabular}

Source: IMF staff estimates. 
proportional to capital spending. And finally, this estimation of efficiency fails to adequately capture the infrastructure coverage dimension.

- The average estimated efficiency score using the hybrid indicator for sub-Saharan Africa is 0.64 , meaning that sub-Saharan Africa has an efficiency gap of 36 percent compared with its best-performing peers. This is considerably worse than other regions. This estimation of efficiency reflects both the survey-based and physical indicators but does not take into account country-specific conditions and needs.

A comparison of the efficiency scores across sub-Saharan African country groups suggests that investment efficiency in oil exporters tends to be lower than that in non-resource-intensive countries. Within sub-Saharan Africa, countries in the East African Community (EAC) perform better than those in the Central African Economic and Monetary Community (CEMAC) and the West African Economic and Monetary Union (WAEMU) (Table 2). Moreover, performance of sub-Saharan African oil exporters is weaker than that of non-resource-intensive countries.

Table 2. Average Public Investment Efficiency Index

\begin{tabular}{lccc}
\hline Region & Physical indicator & Survey-based indicator & Hybrid indicator \\
\hline Sub-Saharan Africa & 0.4597 & 0.8033 & 0.6417 \\
CEMAC & 0.3046 & 0.6247 & 0.5108 \\
EAC & 0.4875 & 0.8736 & 0.7351 \\
WAEMU & 0.3694 & 0.8137 & 0.6188 \\
Oil exporters & 0.1958 & 0.5938 & 0.2687 \\
Non-resource-intensive & 0.4464 & 0.8577 & 0.6981 \\
Other resource-intensive & 0.6019 & 0.8134 & 0.6563 \\
\hline Source: IMF staff estimates & & &
\end{tabular}

Source: IMF staff estimates.

Note: Central African Economic and Monetary Community (CEMAC), East African Community (EAC), West African Economic and Monetary Union (WAEMU). 


\section{Chapter}

\section{Explaining Public Investment Efficiency in Sub-Saharan African Countries}

This section explores the determinants of public investment efficiency in sub-Saharan African countries by using cross-country regressions. The empirical analysis suggests that strong institutions can play a crucial role in fostering the efficiency of public investment in sub-Saharan African countries.

Empirical literature shows that higher public investment efficiency is generally associated with stronger institutions and low dependency on natural resource revenues. Albino-War and others (2014), Grigoli and Mills (2014), and Gleb and Grassman (2010) found that in countries with weak institutional quality, governments may use capital spending as a vehicle for rent-seeking, which can lead to inefficient public investment. To examine the main determinants of public investment efficiency in sub-Saharan African countries, the previously estimated efficiency scores ${ }^{1}$ are regressed over the period $2000-15$ on a set of explanatory variables such as (1) quality of institutions, measured by two World Development Indicators (control of corruption and regulatory quality); ${ }^{2}(2)$ official development assistance; (3) percentage of urban population; ${ }^{3}$ and (4) natural resources dependency

\footnotetext{
${ }^{1}$ The sample comprises 154 countries, including 45 sub-Saharan African countries.

${ }^{2}$ Control of corruption and regulatory quality are measures of perceptions of the quality of institutions. Control of corruption captures perceptions of the extent to which public power is exercised for private gain, including both petty and grand forms of corruption, as well as "capture" of the state by elites and private interests. The estimate gives the country's score on the aggregate indicator in units of a standard normal distribution ranging from approximately -2.5 to 2.5 . Regulatory quality measures perceptions of the ability of the government to formulate and implement sound policies and regulations that permit and promote private sector development. The estimate gives the country's score on the aggregate indicator in units of a standard normal distribution ranging from approximately -2.5 to 2.5. Caution is needed in interpreting the results, as they may be affected by perceptions, recording errors, availability of information, and small sample size.

${ }^{3}$ Urban population refers to people living in urban areas as defined by national statistical offices. The data are collected and smoothed by the United Nations Population Division.
} 
(to capture a country's dependence on its natural resources). ${ }^{4}$ In addition, dummy variables are included for countries that have been under an IMF program $^{5}$ and those that have been in conflict. ${ }^{6}$

Cross-country regressions suggest that the quality of institutions is the main determinant of public investment efficiency in sub-Saharan African countries. Overall, the Ordinary Least Squares (OLS) estimations show a positive correlation between public investment efficiency and the quality of institutions (Table 3). However, a caveat is that the empirical analysis regarding natural resources dependency was not statistically significant.

Using an alternative empirical methodology (Tobit model) and a different measure of institutional quality (survey-based efficiency scores) did not significantly affect the results (Table 4 and Annex 3). The impact of institutional quality on public investment efficiency is significant using both measures of efficiency scores and both empirical methodologies.

Strong institutions can play a crucial role in fostering the efficiency of public investment in sub-Saharan African countries. Based on various specifications, a 10 percent increase in the control of corruption index or the regulatory quality index could improve public investment efficiency in sub-Saharan African countries by about 12 percent on average and could lead to a reduction in sub-Saharan Africa's efficiency gap. Sub-Saharan African countries should speed up the necessary institutional reforms (which will require significant legal and institutional changes) to get more growth for their investment. Obviously, institutional changes cannot be introduced overnight; they will require the development of new skills and capacities, and time to deliver the envisaged benefits.

\footnotetext{
${ }^{4}$ A dummy variable was constructed with 1 being a Low-Income Country (LIC) or a Low Middle-Income Country (LMIC) that is rich in nonrenewable natural resources.

${ }^{5}$ The dummy is equal to 1 if a country was under an IMF program for more than seven years between 2000 and 2015 .

${ }^{6}$ The dummy is equal to 1 if a country was in conflict for more than seven years between 2000 and 2015.
} 


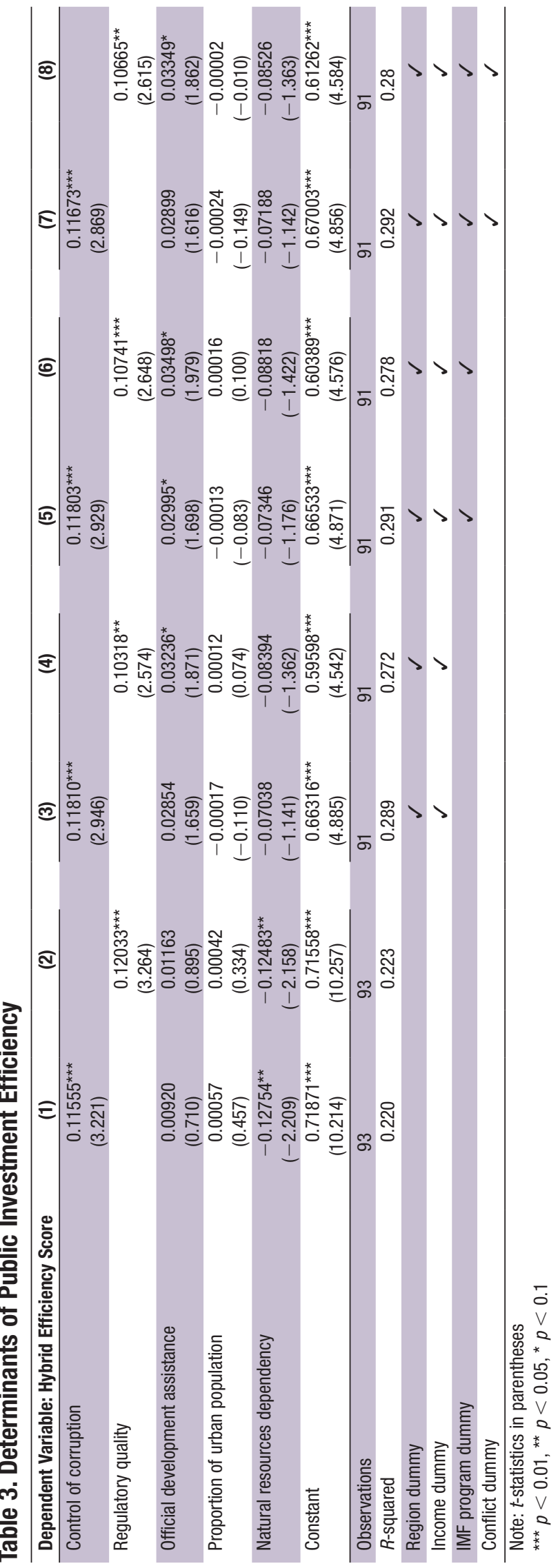




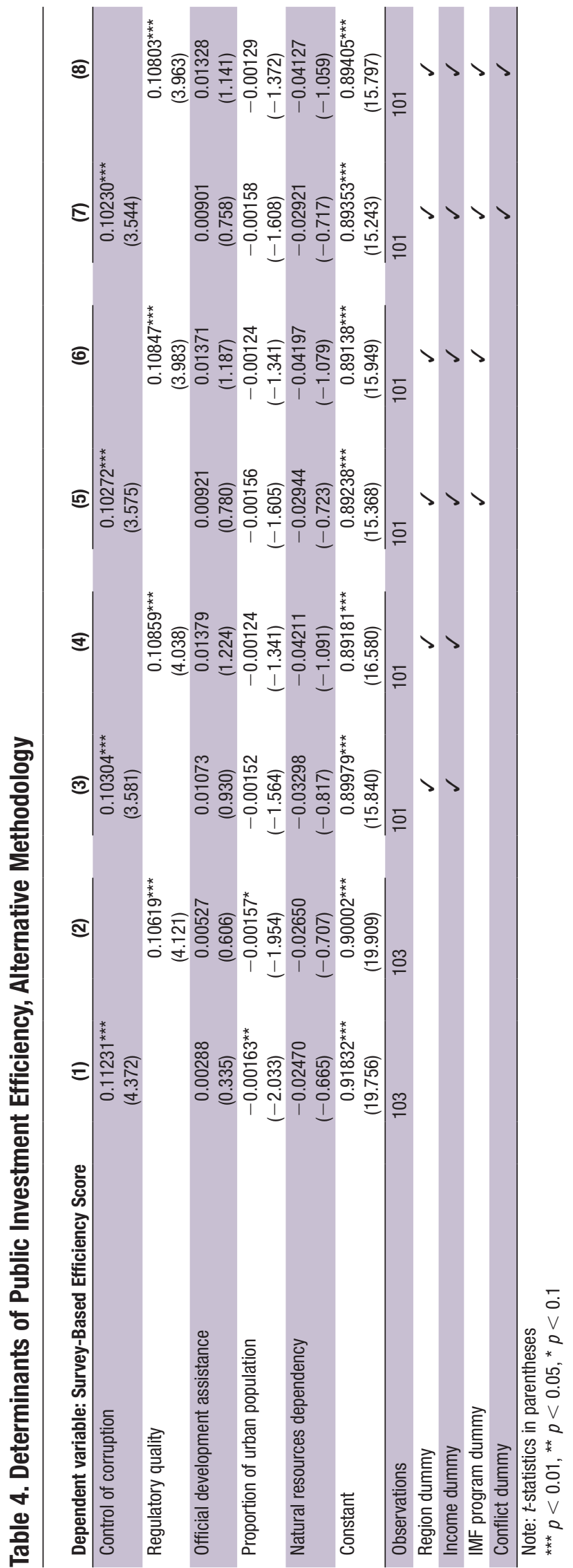




\section{ChAPTER}

\section{Reducing the Efficiency Gap in Sub-Saharan Africa}

This section explores the determinants of public investment efficiency in sub-Saharan Africa. Based on the Public Investment Management Assessment (PIMA) developed by IMF staff, the analysis presented in this section suggests that improvement in public investment management practices in sub-Saharan African countries could significantly reduce their efficiency gap. In particular, sub-Saharan African countries could improve public investment efficiency by strengthening planning and selection of private-public partnerships (PPPs), credibility of multiyear budgeting, effectiveness of project appraisal and selection, monitoring of projects during implementation, and registration of infrastructure assets.

\section{Background}

The differences in the efficiency of public investment across sub-Saharan African countries are in part a function of the relative strength of their PIM institutions. The impact of public investment on infrastructure quality and economic performance is, of course, mediated by a range of factors, including level of economic development, quality of governance, geography, and climate. However, a growing body of literature underscores the role of legal, institutional, and procedural arrangements in determining the level, composition, and impact of public investment.

IMF staff have developed the PIMA to identify the primary areas for strengthening public investment efficiency. The PIMA evaluates 15 key institutions for planning, allocation, and implementation of public investment (see Annex 1 for more details). 
Figure 8. PIMA Scores: Institutional Design

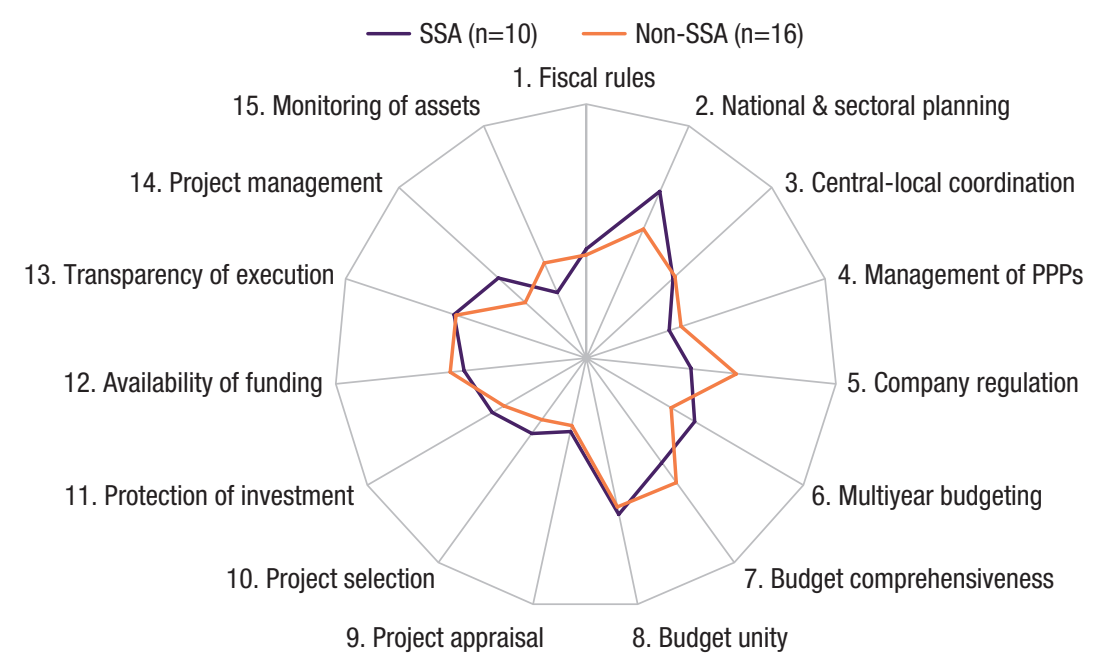

Source: IMF staff estimates.

Note: Public Investment Management Assessment (PIMA).

\section{Results of the PIMA Evaluation in Sub-Saharan African Countries}

The initial PIMA results for 26 piloted countries show that sub-Saharan African countries ${ }^{1}$ have institutional design scores that are generally similar to the average in other regions. ${ }^{2}$ Figure 8 shows the average scores for institutional design for 10 sub-Saharan African countries and 16 non-sub-Saharan African countries. Overall, sub-Saharan African countries have institutional design scores similar to the average in other regions in the world. Sub-Saharan African countries seem to have slightly better institutional design in the areas of national and sectoral planning, multiyear budgeting, and project management, but weaker institutional design in the areas of management of PPPs, company regulation, budget comprehensiveness, availability of funding, and monitoring of assets.

The initial PIMA results also show that sub-Saharan African countries have effectiveness scores that are generally similar to the average in other regions. Figure 9 shows the average scores for effectiveness of the design in practice

\footnotetext{
${ }^{1}$ The sub-Saharan Africa sample consists of Burkina Faso, Cameroon, Côte d'Ivoire, Ghana, Liberia, Madagascar, Mozambique, Togo, and Zambia (developing Africa), and Botswana and Mauritius (emerging Africa)

${ }^{2}$ The non-sub-Saharan Africa sample consists of Maldives, Timor Leste, Malaysia, and Mongolia (emerging and developing Asia); Albania, Ireland, Kosovo, Kyrgyz Republic, Serbia, and Ukraine (advanced, emerging, and developing Europe); Jordan and Morocco (emerging Middle East); and Brazil, Guyana, Honduras, and Peru (emerging and developing Latin America).
} 
Figure 9. PIMA Scores: Effectiveness

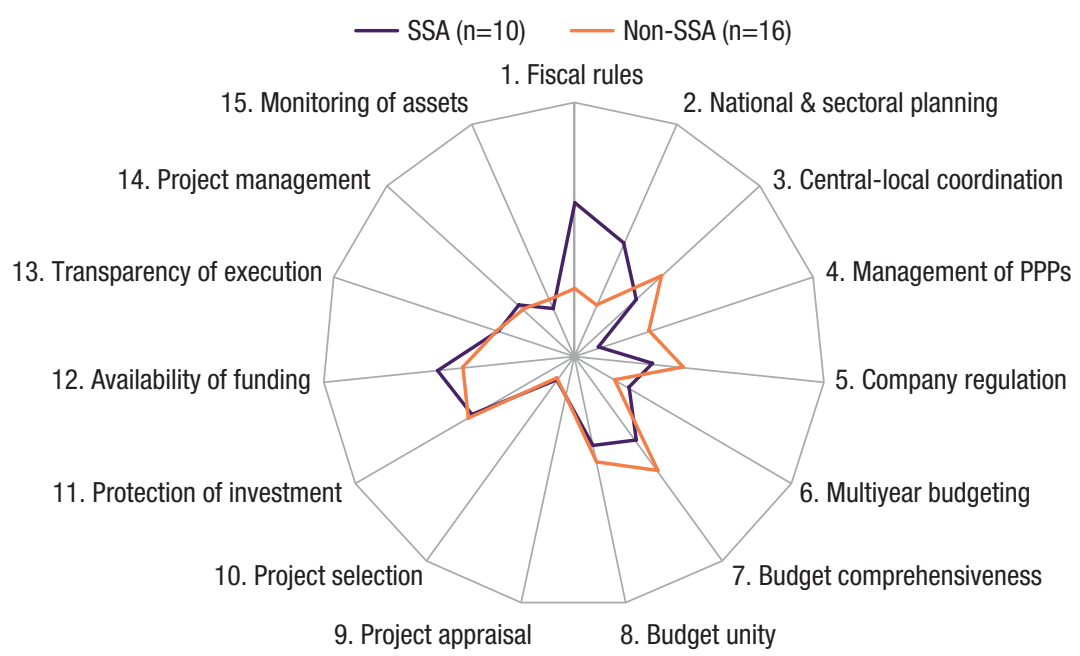

Source: IMF staff estimates.

Note: Public Investment Management Assessment (PIMA).

for sub-Saharan African and non-sub-Saharan African countries. Overall, sub-Saharan African countries have effectiveness scores similar to the averages in other regions. Sub-Saharan Africa seems to be considerably more effective than non-sub-Saharan Africa in the areas of fiscal rules, national and sectoral planning, and availability of funding but relatively less effective in the areas of management of PPPs, central-local coordination, company regulation, and budget comprehensiveness.

Although sub-Saharan Africa scores relatively well on paper, its public investment management is less effective in practice. Figure 10 compares PIMA scores for sub-Saharan Africa on institutional design ${ }^{3}$ and effectiveness. ${ }^{4}$ In the areas of management of PPPs, multiyear budgeting, project appraisal and selection, project management, and monitoring of assets, certain regulations exist but are not used effectively to achieve public investment efficiency. For example, procurement law requires that all projects be tendered in a competitive and transparent manner, but in practice most projects are not.

Overall, potential exists for strengthening a wide range of public investment management for sub-Saharan African countries. In general, sub-Saharan African countries could improve public investment efficiency by strengthening

\footnotetext{
3"Institutional design" refers to the objective fact that an organization, policies, rules, and procedures are in place.

4"Effectiveness" refers to the extent to which the design is achieving its intended purpose or having a clear and useful impact.
} 
Figure 10. PIMA Scores: Institutional Design and Effectiveness

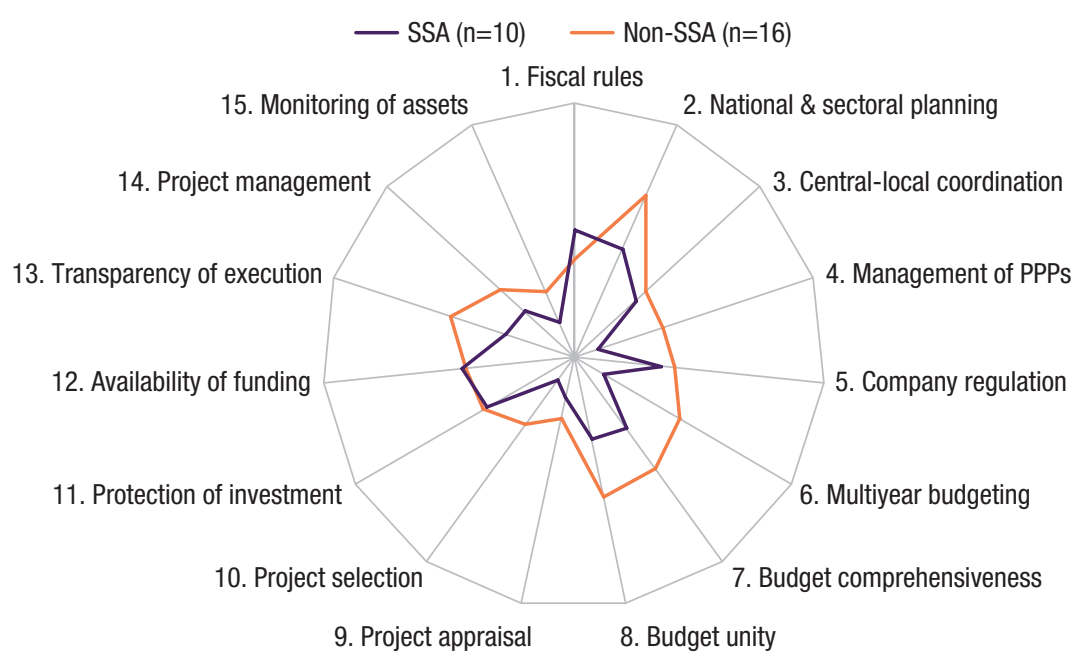

Source: IMF staff estimates.

Note: Public Investment Management Assessment (PIMA).

the planning and selection of PPPs, the credibility of multiyear budgeting, the effectiveness of project appraisal and selection, the monitoring of projects during implementation, and the registration of infrastructure assets. However, each country would have to implement specific reforms, with their sequencing dependent on the country's particular situation. For example, Liberia could improve planning of projects by issuing allotments for budget execution (IMF, 2016). This could be done by establishing and enforcing rules for prioritizing public sector investment program projects and by the payment of counterpart funds to facilitate smoother and more predictable execution of externally financed projects. In addition, Liberia could clarify the roles and responsibilities for public investment management in the Ministry of Finance and Development Planning. The ministry should establish a unit to provide effective financial oversight of PPPs. In Botswana, the government could improve costing and project preparation by introducing a three-phase process covering prefeasibility study, feasibility study, and independent review for large and mega projects (IMF, 2017). It could also require that all PPP projects be assessed and monitored by the PPP unit, regardless of management authority, to ensure adequate oversight of fiscal risks associated with PPPs. 


\section{Conclusion}

There is significant room to improve public investment efficiency in sub-Saharan Africa. Investment in sub-Saharan African countries is lagging vis-à-vis peers such as emerging and developing Asia as well as Latin America and the Caribbean, and the region's infrastructure is perceived as being of relatively low quality. Improving the efficiency of sizable investment programs in the region could contribute to more solid economic growth and help achieve desired social priorities and development goals.

Results point to some variability in public investment efficiency within the region. Comparing efficiency scores across country groups suggests that investment efficiency in sub-Saharan African oil exporters tends to be lower than in sub-Saharan African non-resource-intensive countries. Additionally, countries in East African Community (EAC) perform better than those in Central African Economic and Monetary Community (CEMAC) and West African Economic and Monetary Union (WAEMU).

Stronger institutions could foster more efficient public investment. The regression results in this paper show a positive correlation between public investment efficiency and the quality of institutions, suggesting that developing stronger institutions in sub-Saharan Africa could lead to a significant improvement in investment efficiency. This is particularly relevant for countries with weak institutional quality, where governments may use capital spending as a vehicle for rent-seeking, leading to inefficient spending. Given the current drive for scaling up investment in sub-Saharan Africa, the task of improving institutions quickly should become a priority.

Improvement in public investment management practices in sub-Saharan African countries could significantly reduce their efficiency gaps. While sub-Saharan Africa presents better institutional design in the areas of national and sectoral planning, multiyear budgeting, and project management, the 
region has weaker regulations in the areas of central-local coordination, management of PPPs, company regulation, and monitoring of assets. Sub-Saharan African countries could improve their public investment efficiency by strengthening planning and selection of PPPs, credibility of multiyear budgeting, effectiveness of project appraisal and selection, monitoring of projects during implementation, and registration of infrastructure assets. Other measures to promote greater scrutiny of public investment projects include: (1) improving the procurement process, (2) increasing data transparency and the budgeting process, (3) advancing infrastructure needs assessments to guide medium-term sectoral strategies on infrastructure and monitor progress in closing infrastructure gaps, and (4) undertaking audits and independent in-depth diagnoses of the current public investment management system in coordination with development partners. 


\section{AnNeX 1}

\section{Public Investment Management Assessment}

The Public Investment Management Assessment (PIMA) includes elements similar to those found in other public investment management diagnostic tools, ${ }^{1}$ but it provides a more comprehensive assessment of the investment institutions needed to support decision-making processes at three key stages:

1. Planning sustainable levels of investment across the public sector

2. Allocating investment to the right sectors and projects

3. Implementing productive and durable public investment

This annex discusses the 15 institutions that make up the PIMA framework and describes the methodology used to generate the overall PIMA scores.

Stage 1: Planning. Efficient planning requires institutions that ensure public investment is fiscally sustainable and effectively coordinated across sectors and levels of government, and between public and private sectors. The PIMA assesses whether countries have the following:

- Fiscal principles or rules to ensure overall levels of public investment that are adequate, predictable, and sustainable;

- National and sectoral plans to ensure that public investment decisions are based on clear and realistic priorities, cost estimates, and objectives for each sector;

- Central-local coordination arrangements that integrate public investment plans across levels of government, provide certainty about funding from the central government, and ensure sustainable levels of subnational borrowing;

- Management of public-private partnerships (PPPs) to ensure effective evaluation, selection, and monitoring of PPP projects and liabilities; and

${ }^{1}$ These tools include the Public Investment Management Index (Dabla-Norris and others 2012) and the World Bank's unified framework (Rajaram, 2014). 
- Regulation of infrastructure companies ${ }^{2}$ to ensure open and competitive markets for the provision of infrastructure services, objective pricing of infrastructure outputs, and effective oversight of infrastructure company investment plans.

Stage 2: Allocation. Allocation of capital spending to the most productive sectors and projects requires a comprehensive, unified, and medium-term perspective on capital budgeting as well as objective criteria and competitive procedures for appraising and selecting investment projects. The PIMA assesses the following:

- Multiyear budgeting that provides transparency and predictability regarding levels of investment by ministry, program, and project over the medium term;

- Budget comprehensiveness to ensure that all public investment, regardless of the funding channel, is authorized by the legislature and disclosed in the budget documentation;

- Budget unity to ensure that decisions about individual projects take into account both their immediate capital costs and future operating and maintenance costs;

- Project appraisal to ensure that project proposals are subject to a published appraisal using standard methodology and taking potential risks into account and

- Project selection to ensure that projects are systematically vetted, selected on the basis of transparency criteria, and included in a pipeline of approved projects.

Stage 3: Implementation: The timely and cost-effective implementation of public investment projects requires institutions that ensure projects are fully funded, transparently monitored, and effectively managed. The PIMA assesses the following:

- Protection of investment to ensure that project appropriations are sufficient to cover total project costs and cannot be diverted to other projects at the discretion of the executive;

- Availability of funding to allow the planning and commitment of investment projects based on reliable forecasts and timely cash flows from the Treasury;

- Transparency of budget execution to ensure that major investment projects are tendered in a competitive and transparent process, monitored during project implementation, and independently audited;

- Management of project implementation that identifies an accountable project manager working in accordance with approved implementation

${ }^{2}$ Examples are regulated private sector companies in the telecom, energy, transport, and water sectors. 


\section{Annex Figure 1.1. Public Investment Management Assessment Framework}

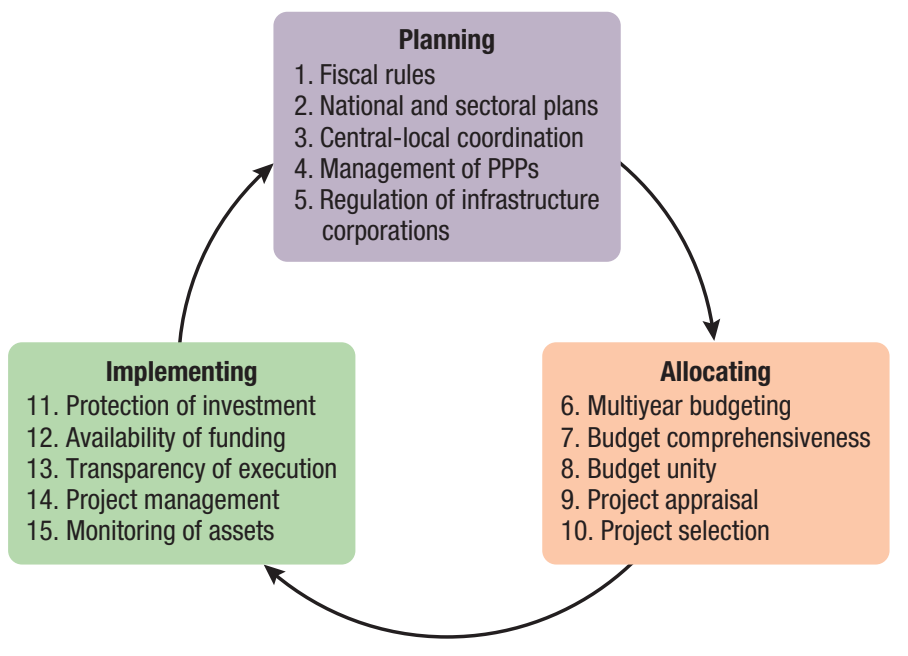

plans and that provides standardized procedures and guidelines for project adjustments; and

- Monitoring of public assets to ensure that assets are properly recorded and reported and their depreciation is recognized in financial statements.

\section{Public Investment Management Assessment Methodology}

Fifteen institutions constitute the framework for the PIMA. For each of the 15 PIM institutions, three key design features are identified, each of which can be fully met, partly met, or not met. Depending on how many of these key features are in place, countries are given a PIMA score of between 0 (no key features in place) and 10 (all 45 key features fully in place). The PIMA improves on other evaluations of public investment management in several ways. It is more comprehensive, bringing in elements related to macro-fiscal frameworks, integration of investment planning in medium-term budgeting, coordination of public investment across levels of government, and private sector participation in the provision of public infrastructure. The framework is also more relevant to countries at the upper end of the income scale, reflecting more advanced practices in the areas of fiscal rules, management of PPPs, project appraisal and selection, and monitoring of public assets. 



\section{Data Envelopment Analysis Methodology}

The methodological framework for measuring the efficiency of production units is based on a production function approach that characterizes the technical efficiency frontier. This frontier provides the benchmark for measuring the relative efficiency of observed production units. In Annex Figure 2.1, the distance $B C$ shows the amount by which output could be increased while leaving input consumption unchanged $\left(\mathrm{X}_{1}\right)$, measuring efficiency.

The measurement of economic efficiency is linked to the use of frontier functions, which begins with a seminal paper by Farrell (1957). Farrell was greatly influenced by Koopmans' (1951) formal definition and Debreu's (1951) measure of technical efficiency. He introduced a method to decompose the overall efficiency of a production unit into its technical and allocative components. ${ }^{1}$

Following Farrell (1957) and assuming constant returns to scale (CRS), the technological set is fully described by the unit isoquant $Y Y^{\prime}$, which captures the minimum combination of inputs per unit of output needed to produce a unit of output. Hence, a set of inputs along the unit isoquant is considered as technically efficient while any point above and to the right of it (that is, point $P$ ) defines a technically inefficient producer, as the combination of inputs is more than enough to produce a unit of output. Hence, the distance $R P$ along the ray $O P$ measures the technical inefficiency of the producer located at point $P$, representing the amount by which all inputs can be divided without decreasing the amount of output. Geometrically, the technical inefficiency level associated with the combination of inputs $P$ can be expressed by the ratio $R P / O P$; therefore, the technical efficiency (TE) of the producer under analysis $(1-R P / O P)$ would be given by the ratio $O R / O P$.

${ }^{1}$ Murillo-Zamorano (2004) provides a comprehensive review of both methods. 


\section{Annex Figure 2.1. Efficiency Frontier}

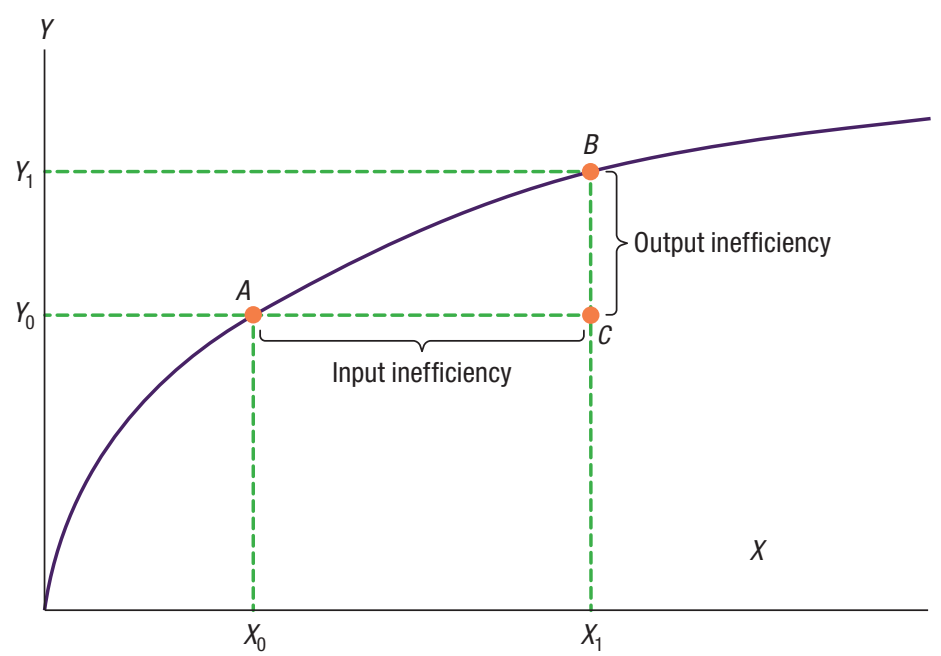

Given market prices and pursuing cost minimization, the input price ratio is reflected by the slope of the isocost-line $C C$; allocative inefficiency can also be derived from the unit isoquant plotted in Annex Figure 2.2. The relevant distance is given by the line segment $S R$, which in relative terms would be the ratio $S R / O R$. With respect to the least-cost combination of inputs given by point $R$, that ratio indicates the cost reduction that a producer would be able to reach if it moved from a technically but not allocatively efficient input package $(R)$ to a technically and allocatively efficient one $\left(R^{\prime}\right)$. Therefore, the allocative efficiency (AE) that characterizes the producer at point $P$ is given by the ratio $O S / O R$, and economic efficiency (EE) is measured as the multiplicative interaction of both technical and allocative components:

$$
\mathrm{EE}=\mathrm{TE} \times \mathrm{AE}=\frac{O R}{O P} \times \frac{O S}{O R}=\frac{O S}{O P}
$$

where the distance involved in its definition $(S P)$ can also be analyzed in terms of cost reduction.

Efficiency frontiers can be estimated using parametric or nonparametric methods. Under parametric methods, an econometric model is estimated, assuming that input-output combinations lie below the efficiency frontier, requiring strict assumptions on the stochastic distribution of errors and the functional form underlining the model, and controlling for the variation in output unexplained by the inputs. The nonparametric approach is based on linear programming methods but is sensitive to the presence of measurement errors and outliers. 


\section{Annex Figure 2.2. Technical and Allocative Efficiency Measures}

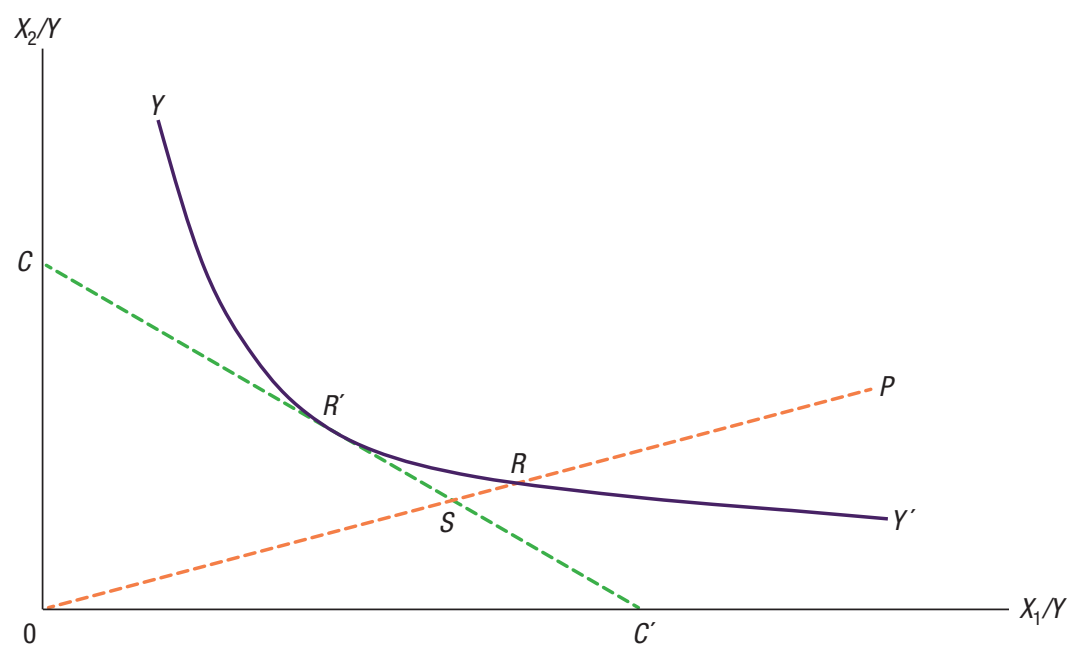

The data envelopment analysis (DEA) methodology is based on nonparametric methods, estimating the efficient frontier through linear approximations enveloping all decision-making unit (DMU) performance observations. ${ }^{2}$ Efficiency scores are then calculated relative to a peer group consisting of linear combinations of input-output observations for efficient DMUs. Efficiency scores indicate the proportional amount by which countries could increase the quality of their infrastructure while leaving public capital (and other inputs) unchanged. The estimation assumes factor homogeneity (that is, the quality of inputs is similar among countries) and adds per capita GPD as a control variable. Three different indicators are used to measure infrastructure output:

- A physical indicator. A pure quantitative index that captures the use of public investment (construction of infrastructure and the provision of social services such as health and education), which is standardized and combined as follows using similar weights to obtain the output indicator $(y i)$.

$$
y_{i}=\sum_{j=1}^{4}\left(\frac{1}{5}\right)\left(\frac{x_{i j}-\bar{x}_{j}}{\sigma_{i j}}\right)
$$

\footnotetext{
${ }^{2}$ The original DEA model assumes constant return to scale, which implies that all DMUs in the sample are performing at an optimal scale. This paper uses a DEA with variable return to scale, allowing comparisons of DMUs with other counties with similar characteristics.
} 
where $x_{i j}$ is the value of the variable $j$ in country $i$, is the mean of variable $j$ for all countries, and $\sigma_{i j}$ is the standard deviation of variable $j$ in country $i$ over the considered period.

- A survey-based indicator. This is an index built on the World Economic Forum pillar 2 subcomponents focusing on the quality of key infrastructure services.

- A hybrid indicator. This is the mean of the two previously described indicators and provides a measure of both the coverage and quality of public infrastructure. 
AnNeX 3

\section{Alternative Methodology}




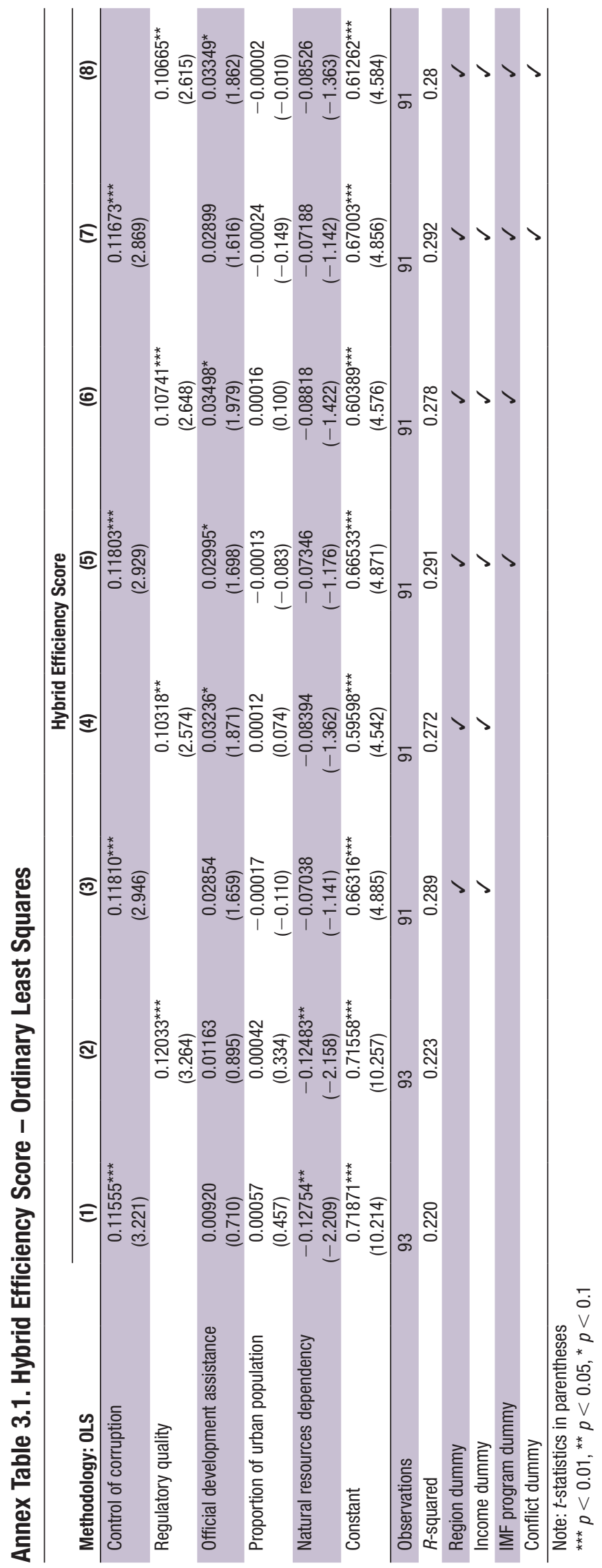




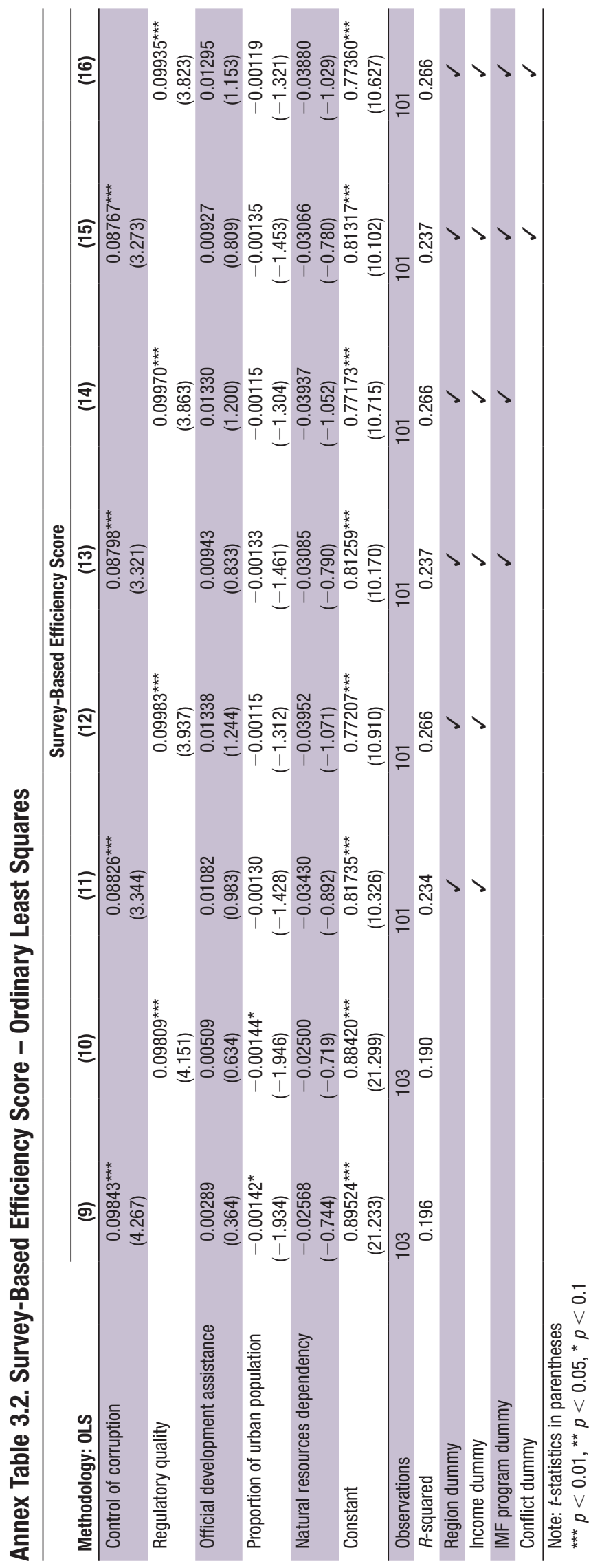




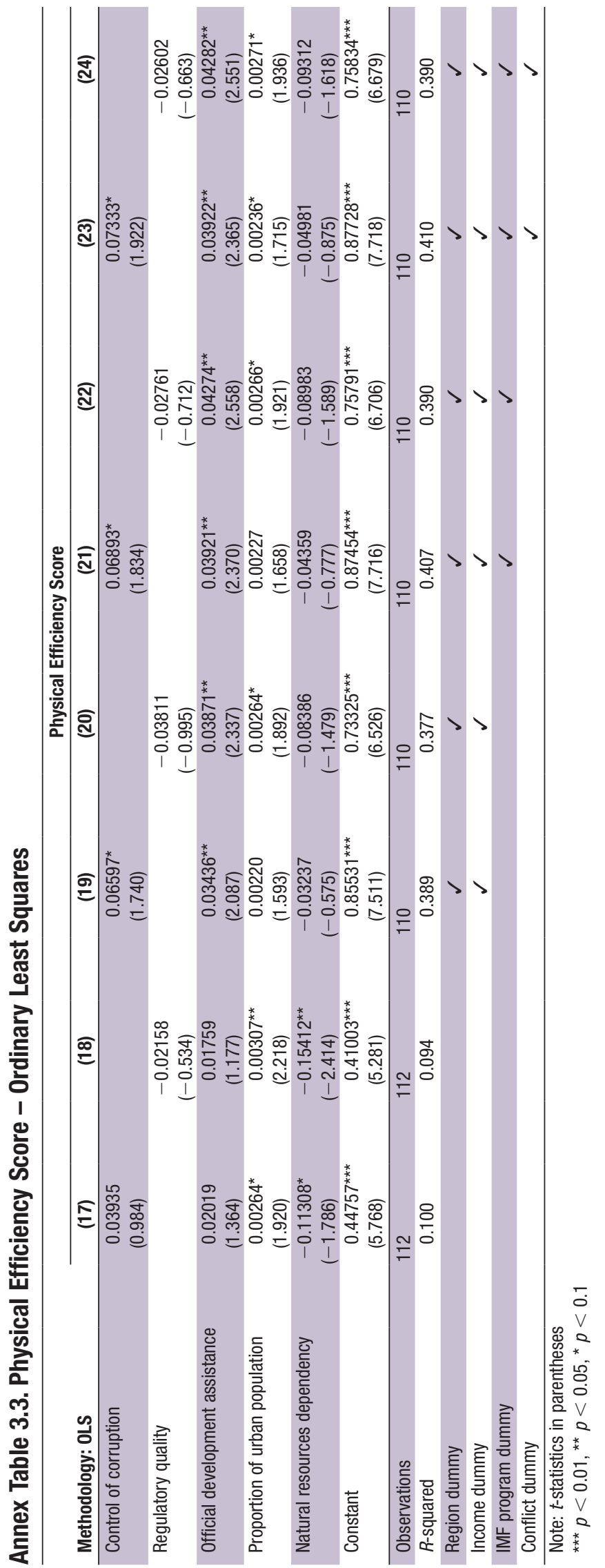




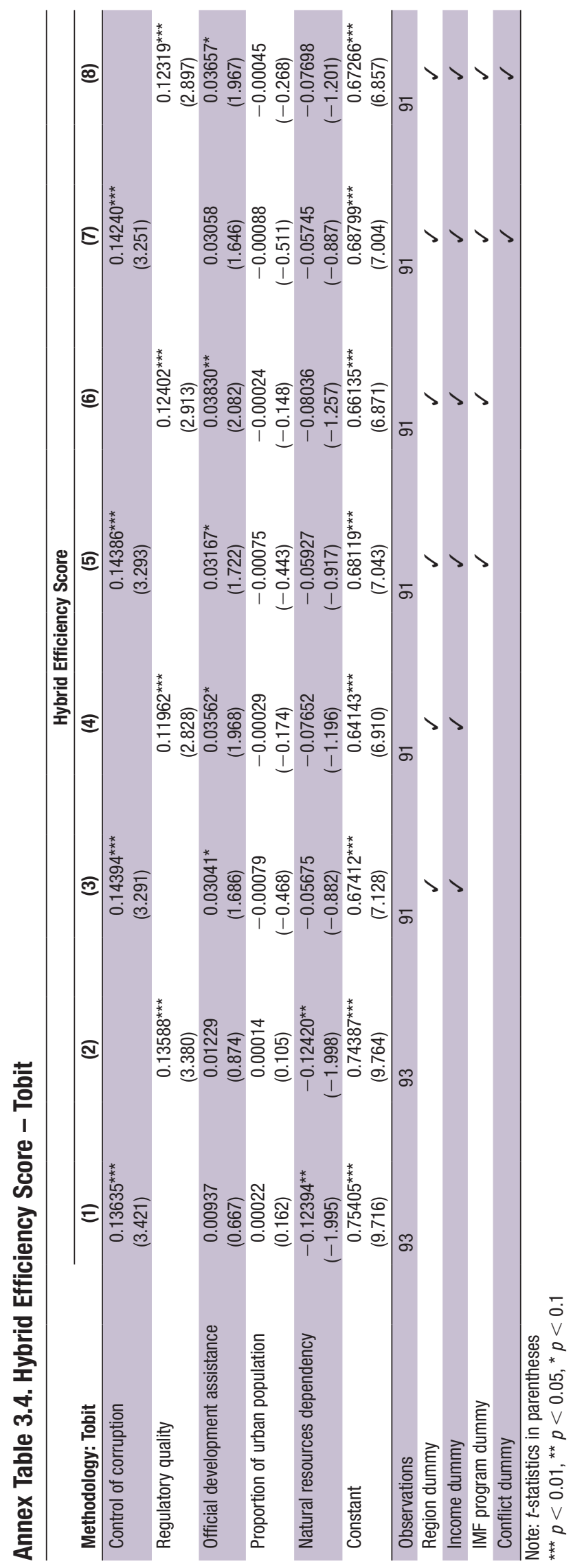




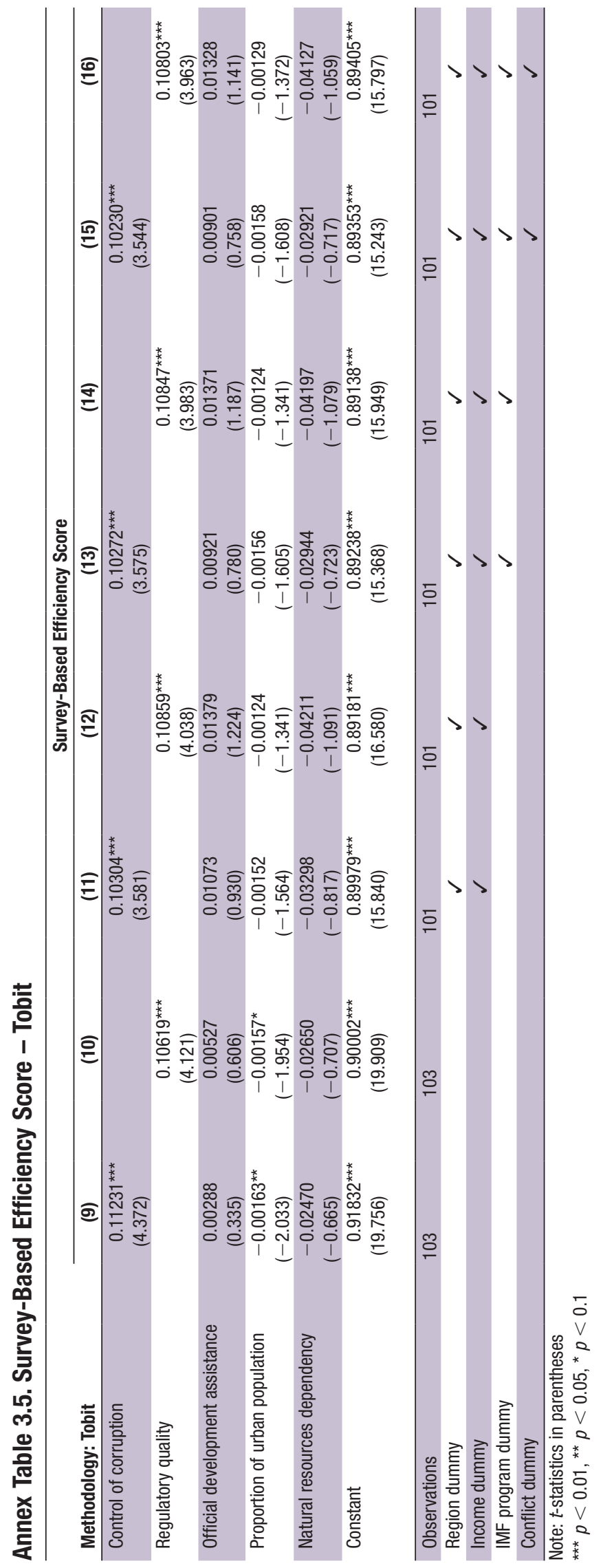




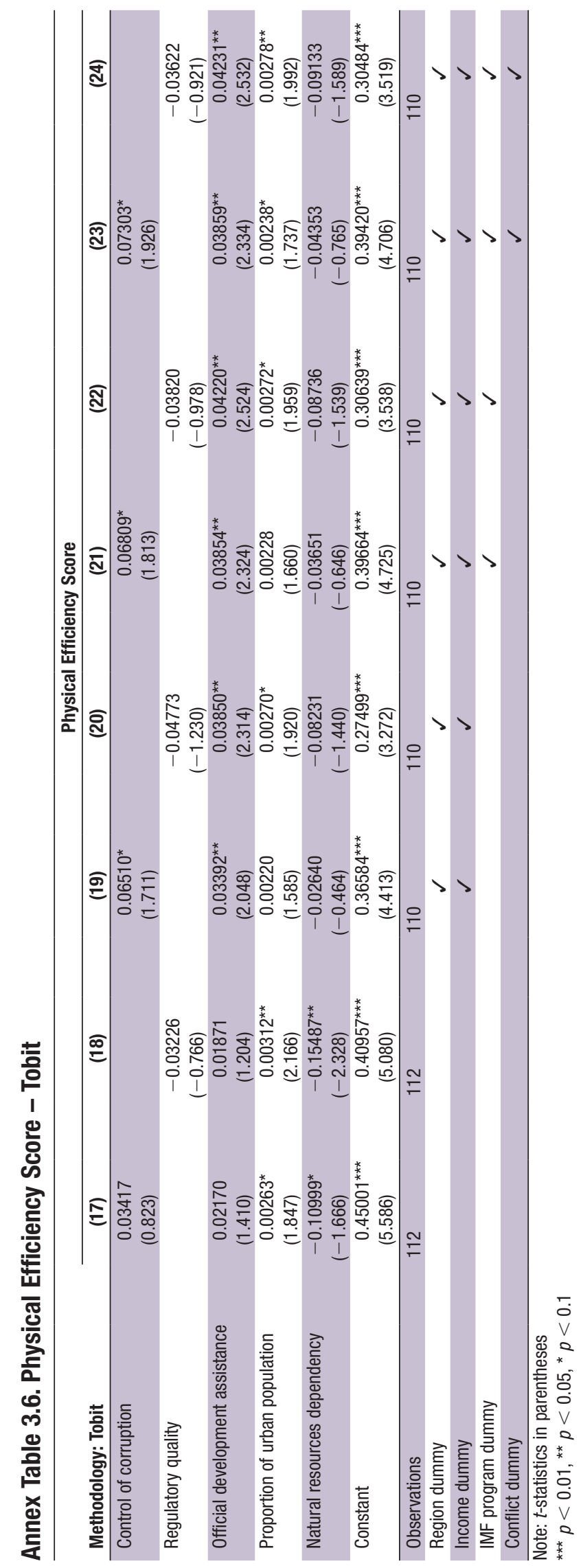





\section{References}

Aghion, Philippe., and Peter Howitt. 2009. "The Economics of Growth.” MIT Press, Cambridge, MA.

Albino-War, Maria, Svetlana Cerovic, Francesco Grigoli, Juan Carlos Flores, Javier Kapsoli, Haonan Qu, Yahia Said, Bahrom Shukurov, Martin Sommer, and SeokHyun Yoon. 2014. "Making the Most of Public Investment in MENA and CCA Oil-Exporting Countries." IMF Staff Discussion Note 14/10, International Monetary Fund, Washington, DC.

Barro, Robert J., and Jong-Wha Lee. 1993. "International Comparisons of Educational Attainment.” Journal of Monetary Economics 32 (3): 363-94.

Berg, Andrew, Edward F Buffie, Catherine A Pattillo, Rafael Portillo, Andrea Presbitero, and Luis-Felipe Zanna. 2015. "Some Misconceptions about Public Investment Efficiency and Growth.” IMF Working Paper 15/272, International Monetary Fund, Washington, DC.

Bornhorst, Fabian, Serkan Arslanalp, Sanjeev Gupta, and Elsa Sze. 2010. "Public Capital and Growth." IMF Working Paper 10/175, International Monetary Fund, Washington, DC.

Calderón, César, and Luis Servén. 2004. "The Effects of Infrastructure Development on Growth and Income Distribution.” Working Paper 270, Central Bank of Chile, Santiago.

Collier, Paul, Frederick van der Ploeg, and Anthony J. Venables. 2009. “Managing Resource Revenues in Developing Countries.” OxCarre Research Paper 2009-14, University of Oxford, Oxford, England.

Dabla-Norris, Era, Richard Allen, Luis-Felipe Zanna, Tej Prakash, Eteri Kvintradze, Victor Lledo, Irene Yackovlev, and Sophia Gollwitzer. 2011. "Budget Institutions and Fiscal Performance in Low-Income Countries." IMF Working Paper 10/80, International Monetary Fund, Washington, DC. 
Dabla-Norris Era., Jim Brumby, Annette Kyobe, Zac Mills and Chris Papageorgiou. 2012. "Investing in Public Investment: An Index of Public Investment Efficiency.” Journal of Economic Growth 17 (3): 235-266.

Debreu, Gerard. 1951. “The Coefficient of Resource Utilization.” Econometrica 19 (3): 273-92.

Farrell, M. J. 1957. “The Measurement of Productive Efficiency.” Journal of the Royal Statistical Society 120: 253-81.

Gelb, Alan, and Sina Grassman. 2010. "How Should Oil Exporters Spend Their Rents?” Working Paper 221, Center for Global Development, Washington, DC.

Grigoli, Francesco, and Javier Kapsoli. 2013. "Waste Not: The Efficiency of Health Expenditure in Emerging and Developing Countries." IMF Working Paper 13/87, International Monetary Fund, Washington, DC.

Grigoli, Francesco, and Zachary Mills. 2014. "Institutions and Public Investment: An Empirical Analysis.” Economics of Governance 15 (2): 131-153.

Gupta, Sanjeev, Alvar Kangur, Chris Papageorgiou, and Abdoul Wane. 2014. "Efficiency-Adjusted Public Capital and Growth." World Development 57 (C): 164-178.

Herrera, Santiago, and Gaobo Pang. 2005. "Efficiency of Public Spending in Developing Countries: An Efficiency Frontier Approach.” Policy Research Working Paper 3645, World Bank, Washington, DC.

International Monetary Fund (IMF). 2014. "Chapter 3: Is It Time for An Infrastructure Push? The Macroeconomic Effects on Public Investment." In World Economic Outlook: Legacies, Clouds, Uncertainties. Washington, DC, October.

2015a. "Making Public Investment More Efficient." IMF Policy Paper, International Monetary Fund, Washington, DC.

2015b. "Chapter 4: Private Investment. What's the Holdup?"

In World Economic Outlook: Legacies, Clouds, Uncertainties. Washington, DC, April.

2016. "Liberia: Technical Assistance Report-Public Investment Management Assessment.” IMF Country Report 16/352, International Monetary Fund, Washington, DC.

2017. "Botswana: Technical Assistance Report-Public Investment Management Assessment.” IMF Country Report 17/188, International Monetary Fund, Washington, DC. 
Keefer, Philip, and Stephen Knack. 2007. "Boondoggles, Rent-Seeking, and Political Checks and Balances: Public Investment under Unaccountable Governments." Review of Economics and Statistics 89 (3): 566-72.

Koopmans, Tjalling C. 1951. "An Analysis of Production as Efficient Combination of Activities." In Activity Analysis of Production and Allocation, edited by T. C. Koopmans, Monograph 13. New York: Cowles Commission for Research in Economics.

McKinsey Global Institute. 2013. "Infrastructure Productivity. How to Save \$1 Trillion a Year,” McKinsey and Company, London, England.

Murillo-Zamorano, Luis R. 2004. "Economic Efficiency and Frontier Techniques." Journal of Economic Surveys 18 (1): 33-77.

Organisation for Economic Co-operation and Development (OECD). 2014. "Recommendation of the Council on Effective Public Investment Across Levels of Government." OECD, Paris. http://www.oecd.org/regional-policy.

Rajaram, Anand, Tuan Minh Le, Kai Kaiser, Jay-Hyung Kim, and Jonas Frank. 2014. "The Power of Public Investment Management: Transforming Resources into Assets for Growth” Directions in Development-Public Sector Governance, World Bank Group, Washington, DC.

Warner, A. 2014. "Public Investment as an Engine of Growth." IMF Working Paper 14/148, International Monetary Fund, Washington, DC.

World Bank. 2006. "Appraisal of Public Investment: Chile” World Bank, Washington, DC.

. 2011. "Strengthening Public Investment Management." World Bank, Washington, DC. 
